\title{
Molecular Phylogeny and Phylogeography of Potentilla multifida L. agg. (Rosaceae) in Northern Eurasia with Special Focus on Two Rare and Critically Endangered Endemic Species, P. volgarica and P. eversmanniana
}

\author{
Ivan A. Schanzer ${ }^{1, *} \mathbb{D}$, Alina V. Fedorova ${ }^{1}$, Olga V. Shelepova ${ }^{1}$ \\ and Guzyaliya F. Suleymanova 2,3 (D) \\ 1 Tsitsin Main Botanical Garden of Russian Academy of Sciences, Botanicheskaya Str., 4, \\ 127276 Moscow, Russia; alina_77777@mail.ru (A.V.F.); shov_gbsad@mail.ru (O.V.S.) \\ 2 Khvalynsky National Park, Oktyabrskaya Str., 2B, 412787 Khvalynsk, Russia; suleymanovagf@mail.ru \\ 3 Saratov State University, Astrakhanskaya Str., 83, 410012 Saratov, Russia \\ * Correspondence: ischanzer@gmail.com; Tel.: +7-915-362-1911
}

Received: 5 November 2020; Accepted: 17 December 2020; Published: 18 December 2020

\begin{abstract}
The results of a molecular genetic study of Potentilla multifida agg. using two plastid markers (ndhC-trnV and $p s b A-t r n H$ ) and a nuclear ITS marker suggested that this group comprises a number of relatively young and incompletely differentiated species widely distributed in Northern Eurasia. The sequences were analyzed using tree-based (maximum likelihood) and network-based (statistical parsimony network) approaches. The plastid data suggested incomplete lineage sorting, characteristic of the group as a whole. The nuclear ITS results demonstrated quite a different pattern, with mostly conspecific accessions shaping monophyletic clades. The majority of the Potentilla sect. Multifidae species studied possess few, usually closely related plastid haplotypes, or are even monomorphic. In contrast, P. volgarica, a narrow endemic from the Volga River valley, presents plastid haplotypes belonging to two distantly related groups. Such a pattern of genetic diversity in $P$. volgarica may be explained by a long persistence of the species within an extremely small distribution range, on the right bank of the Volga River, most likely representing a contemporary refugium. The genealogy of plastid markers in P. volgarica suggests that this species is ancestral to P. eversmanniana, another narrow endemic from the $\mathrm{S}$ Urals.
\end{abstract}

Keywords: Potentilla sect. Multifida; Potentilla volgarica; Potentilla eversmanniana; Potentilla multifida agg.; $n d h C-t r n V ; p s b A$-trnH; ITS; genetic polymorphism; plastid haplotype genealogy

\section{Introduction}

The genus Potentilla L. comprises more than 300 species distributed worldwide in temperate areas and in mountainous regions in the tropics [1-3]. Hybridization, polyploidy, and apomixis are not rare among its species [4-10], which make the taxonomy of the group very complicated. The existing phylogenies of Potentilla and the Potentilleae tribe are based on relatively small subsets of taxa and are still far from comprehensive [2,11-15]. Even in the cases where the taxa sets of Potentilleae were quite comprehensive [2,13], some groups of Potentilla s. str. were underrepresented, including those that are the focus of our study. The taxonomy of the genus is, similarly, far from a definite assessment. Despite the existence of a number of relatively recent regional revisions and critical taxonomic accounts $[7,16-21]$ the taxonomic system of the genus are still based on the monograph by 
Th. Wolf [1], and no comprehensive revision encompassing the whole genus has been done recently. Moreover, the very limits of the genus are subject to reconsideration in the light of recent phylogenetic studies that call into question the taxonomic rank of such groups as Argentina Hill, Ivesia Torr. \& A. Gray, and Horkelia Cham. \& Schltdl.

The genus includes many common widely distributed species along with geographically restricted endemics, some of which are thought to be extremely rare and close to extinction $[22,23]$. Though several species of Potentilla have been thoroughly studied already as to their population structure and phylogeography [24-26], such endangered endemics are not among them. At the same time, the very endemicity and rarity of some species may be questionable, because of the lack of clear-cut delimitation from morphologically similar, widely distributed species. Potentilla volgarica Juz. and P. eversmanniana Fisch. ex Ledeb. represent examples of such a situation. The former species is believed to be an endemic of the Middle Volga River valley in the vicinity of Khvalynsk, Saratov Province, Russia, with a distribution range of a few hundred square kilometers. In the IUCN Red List [22] it was listed as already extinct, but several new populations were later found in the same area [23]. Potentilla eversmanniana is known from a handful of isolated locations in the Southern Urals [7,23]. Its occurrence in Kazakhstan and Mongolia [7,27] is dubious. The IUCN Red List [22] listed it as vulnerable. Both species are included in the Red Data Book of the Russian Federation [23].

Furthermore, the two species are morphologically very similar to each other as well as to the widely distributed species P. multifida L. and P. tergemina Soják, all belonging to Wolf's "grex" Multifidae [1], a group encompassing 27 species distributed through temperate and mountainous areas of Eurasia and North America. In modern works this group is usually assigned the rank of section [7,21]. None of its species was ever studied with molecular genetic methods, nor thoroughly analyzed for morphological variability except for genus or tribal level phylogenetic studies. The group is mostly represented by polyploids: P. tergemina $(2 \mathrm{n}=28,33,36)$, P. multifida $(2 \mathrm{n}=28,42)$, P. agrimonioides M.Bieb. $(2 \mathrm{n}=42$, 49-50), P. anachoretica Soják $(2 \mathrm{n}=28)$, P. ornithopoda Tausch $(2 \mathrm{n}=28,42)$ [28], and P. jenissejensis Polozhij et W.A.Smirnova ( $2 n=4 x$, flow cytometric data) [29]. Many of these species remain taxonomically critical, and the group needs a thorough phylogenetic and taxonomic re-examination. The problem of species delimitation in the P. multifida group in general, and the assessment of the rank of $P$. volgarica and P. eversmanniana, in particular, are evident from a polemic on their taxonomy between two specialists in Potentilla taxonomy, late Professors R. Kamelin [7] and J. Soják [19]. Kamelin considered P. volgarica a "hybrid race of unknown origin", and P. eversmanniana a "hybrid race (P. multifida $\times$ P. conferta) evidently more widely distributed in the past". Soják completely rejected this view and described the two taxa as "clear and indisputable species", differing morphologically primarily in the presence/absence of glandulous hairs on the upper leaf surface. The taxonomic treatment of the section Multifidae (Rydb.)A.Nelson is also controversial. Morphological differences of many species are vague, being essentially based on the number of quantitative characters of number of leaflet pairs, presence and abundance of glands on different parts of the plant, and shape and position of trichomes on the leaf undersurface and petioles. These characters are often dependent on the size and age of the plants. For example, P. volgarica differs from P. eversmanniana in the presence of glands on leaves and the less dense tomentose pubescence of the leaf undersurface $[7,18]$. These characteristics, however, vary considerably among plants in local populations of $P$. volgarica, so that at least some plants do not bear any glands on leaves at all. Moreover, $P$. multifida and P. tergemina, according to available keys, differ only by appressed vs. patent hairs on petioles, the latter character being typical for both $P$. eversmanniana and P. volgarica, albeit the hairs are longer than in P. tergemina. Hence, on morphological grounds, all the samples of P. eversmanniana kept at the Herbarium of Moscow University (MW) should be re-determined as $P$. tergemina having hairs shorter than $3 \mathrm{~mm}$.

Trying to solve the problem of the taxonomic identity of P. eversmanniana and P. volgarica, we studied several populations of both species in the Bashkortostan Republic and Saratov Province of Russia, respectively, covering the whole range of $P$. volgarica. Herbarium collections kept at Moscow Lomonosov State University (MW), Tsitsin Main Botanical Garden (MHA), and Botanical Garden of Saratov State 
University (SARBG) were used to complement these data with specimens from other localities, not studied in the field, and samples of other morphologically similar species, chiefly characterized by deeply dissected leaflets, a key character of the section Multifidae, united by Soják [19] in his P. multifida agg. This enabled us to analyze a significant number of additional accessions.

The aims of the study were as follows:

1. To assess the genetic variability of $P$. volgarica and P. eversmanniana and to test whether they represent two separate species.

2. To assess the genetic distinctions of both species from P. multifida agg. sensu Soják [19] and other related species of the section Multifidae.

3. To assess the phylogenetic relationships of P. multifida agg. species and pinpoint the origin of disjunct isolated populations of P. volgarica and P. eversmanniana in the Russian Plain and the foothills of the Southern Urals, respectively.

\section{Results}

\subsection{Plastid Data Analyses}

The length of the trnH-psbA IGS varied from $376 \mathrm{bp}$ to $488 \mathrm{bp}$ in the ingroup (Potentilla sect. Multifidae) and from $308 \mathrm{bp}$ to $416 \mathrm{bp}$ in the outgroup (Potentilla species from other sections). The length of the $n d h C-t r n V$ IGS varied from $489 \mathrm{bp}$ to $543 \mathrm{bp}$ in the ingroup and from $506 \mathrm{bp}$ to $585 \mathrm{bp}$ in the outgroup. The length of the concatenated alignment was $1215 \mathrm{bp}$. The length of the alignment after trimming with the BMGE (Block Mapping and Gathering with Entropy) v. 1.1. software [30] and manually removing three 'AT' short repeats causing homoplasy in preliminary analyses was reduced to $910 \mathrm{bp}$. The final alignment contained 56 variable positions, of which 19 positions were parsimoniously informative, 37 positions were autapomorphic, and 64 sites were alignment gaps treated as missing data in further analyses.

This trimmed alignment was used for a maximal likelihood analysis (Figure 1), which resulted in the inclusion of sequences of $P$. multifida, P. tergemina, P. anachoretica, P. arctica Lehm., P. agrimonioides, P. aphanes, P. jenissejensis, P. ornithopoda, P. approximata Bunge, P. verticillaris Stephan ex Willd., P. volgarica, $P$. eversmanniana, and $P$. nivea $\mathrm{L}$. into the ingroup. The latter species initially was regarded as an outgroup member. The tree was poorly resolved and sequences of many samples were placed on short or zero length branches. That was indicative of incomplete lineage sorting within and among the taxa of Potentilla analyzed and justified the use of haplotype networks to reconstruct the relationships among them $[31,32]$.

At the second stage, we reduced the alignment by excluding all the distantly related sequences of the outgroup and analyzed the genealogical relations of the ingroup sequences with the statistical parsimony approach realized in the TCS software. Indels were treated as missing data. The program calculated the $95 \%$ parsimony limit of 12 mutational steps and collapsed the sequences into 40 haplotypes united into a single network. Twelve of them were placed into the network as internal haplotypes, connected to two or more neighboring haplotypes. Accordingly, 28 haplotypes were tip haplotypes, connected to a single neighboring haplotype [33]. Further twenty-eight haplotypes were calculated by the program and included into the network as missing hypothetical haplotypes. The network has no loops and is shown in Figure 2. It comprises 12 internal haplotypes designated with capital letters A to $\mathrm{L}$, and 28 tip haplotypes designated with letters and figures. Of course, these haplotype names are conventional and their choice is, to a large extent, driven by the convenience of further network interpretation. The network is unrooted and can be considered as a combination of several variously related haplotype groups, each encompassing internal haplotypes and tip haplotypes derived from them. Their geographical distribution and correspondence to morphological taxa is shown in Figure 3. 


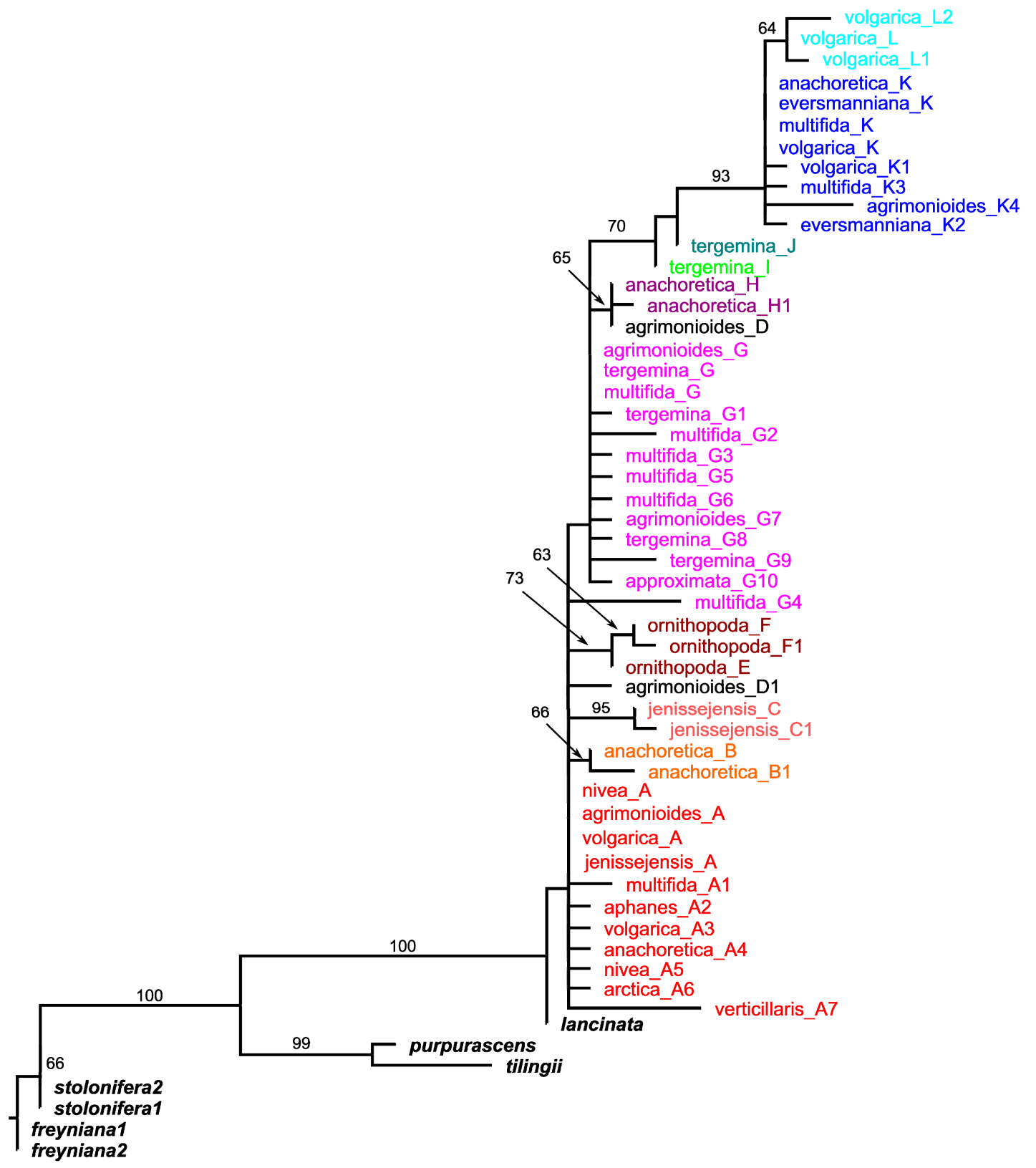

0.02

Figure 1. Maximum likelihood tree of Potentilla multifida agg. based on plastid genomic markers. Terminal names within the ingroup are followed by corresponding haplotype designations. Bootstrap support higher than $50 \%$ is indicated above branches. Different haplotype groups are highlighted with colors corresponding to those in Figure 2.

The second group represents haplotypes descending from internal haplotype G, differing from haplotype A by one mutational step. They include tip haplotypes G1 to G10 differing from haplotype $\mathrm{G}$ by one to four mutational steps, and a lineage comprising internal haplotype $\mathrm{H}$ and tip haplotype H1. Internal haplotype G occurs among samples of P. agrimonioides from the Caucasus, P. multifida from Southern Siberia, and P. tergemina from different parts of its area, including the samples occurring as weeds carried along railways in the European part of Russia and Ukraine. As in the previous case, tip haplotypes are rare and found in solitary samples of several species. Haplotypes G1, G5, G6, G8, G9 are found in P. tergemina, haplotypes G2, G3, and G4 occur in P. multifida, and haplotype G7 is 
characteristic of one sample of P. agrimonioides from the Northern Caucasus. Haplotypes of the H-H1 lineage are exclusively characteristic of $P$. anachoretica from Wrangel Island off the coast of Chukotka in the Arctic Ocean.

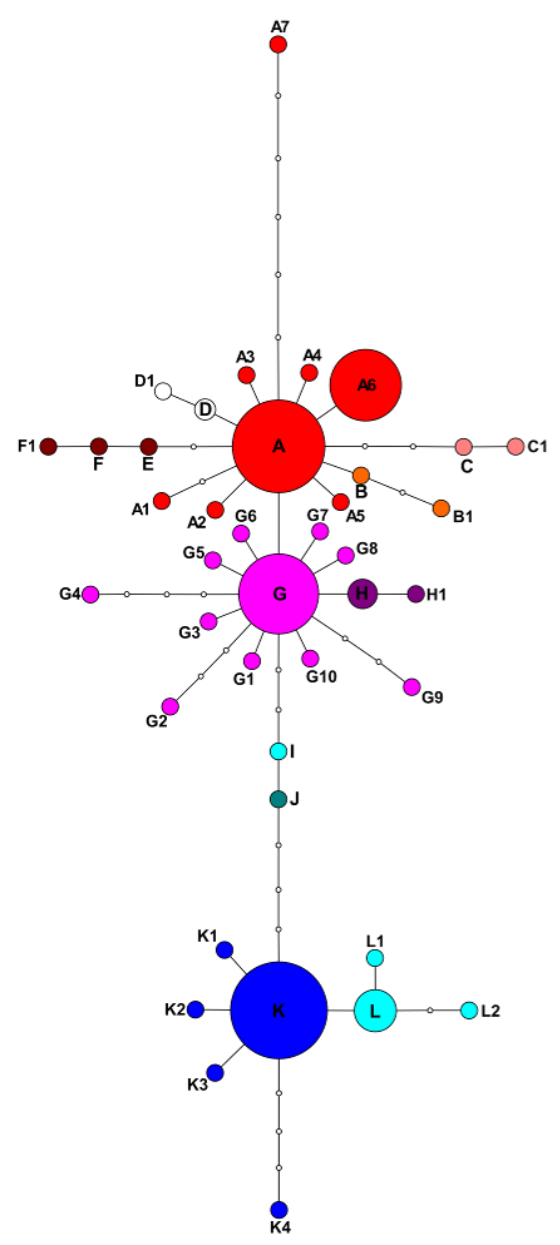

Figure 2. Statistical parsimony network of Potentilla multifida agg. plastid haplotypes. Bold letters designate internal haplotypes, letters and numbers designate tip haplotypes derived from corresponding internal ones. Colors distinguish haplotype lineages. Small empty circles indicate missing hypothetical haplotypes deduced by the program. Each edge corresponds to one mutational step.

The first group of haplotypes comprises tip haplotypes related to internal haplotype A. Most of them differ from internal haplotype A by a single mutational step (A2-A6). Haplotype A1 differs from A by two mutational steps and haplotype A7 differs by six mutational steps. Haplotype A is also ancestral to four lineages encompassing both internal and tip haplotypes, B-B1, C-C1, D-D1, and E-F-F1. The internal haplotype A occurs in populations of P. volgarica (Figure 3) but was also found in single samples of P. agrimonioides from the Altai Mountains., P. jenissejensis from Tyva, and P. nivea from the Caucasus. As to tip haplotypes and the clades descendant from the internal haplotype A, the pattern is more complex. Haplotypes A1-A5 were found in single samples of P. multifida from Tyva, P. aphanes from Southern Tajikistan, P. volgarica from Saratov Province, P. anachoretica from the Taimyr Peninsula, and P. nivea from the Western Caucasus, respectively. Haplotype A6 was uniquely found in multiple samples of $P$. arctica from the shore and islands of the White Sea. Haplotype A7 was found in P. verticillaris from the shore of Lake Baikal. The lineages B-B1, C-C1, D-D1, and E-F-F1 appeared to be species specific for P. anachoretica, P. jenisseiensis, P. agrimonioides, and P. ornithopoda, respectively. 


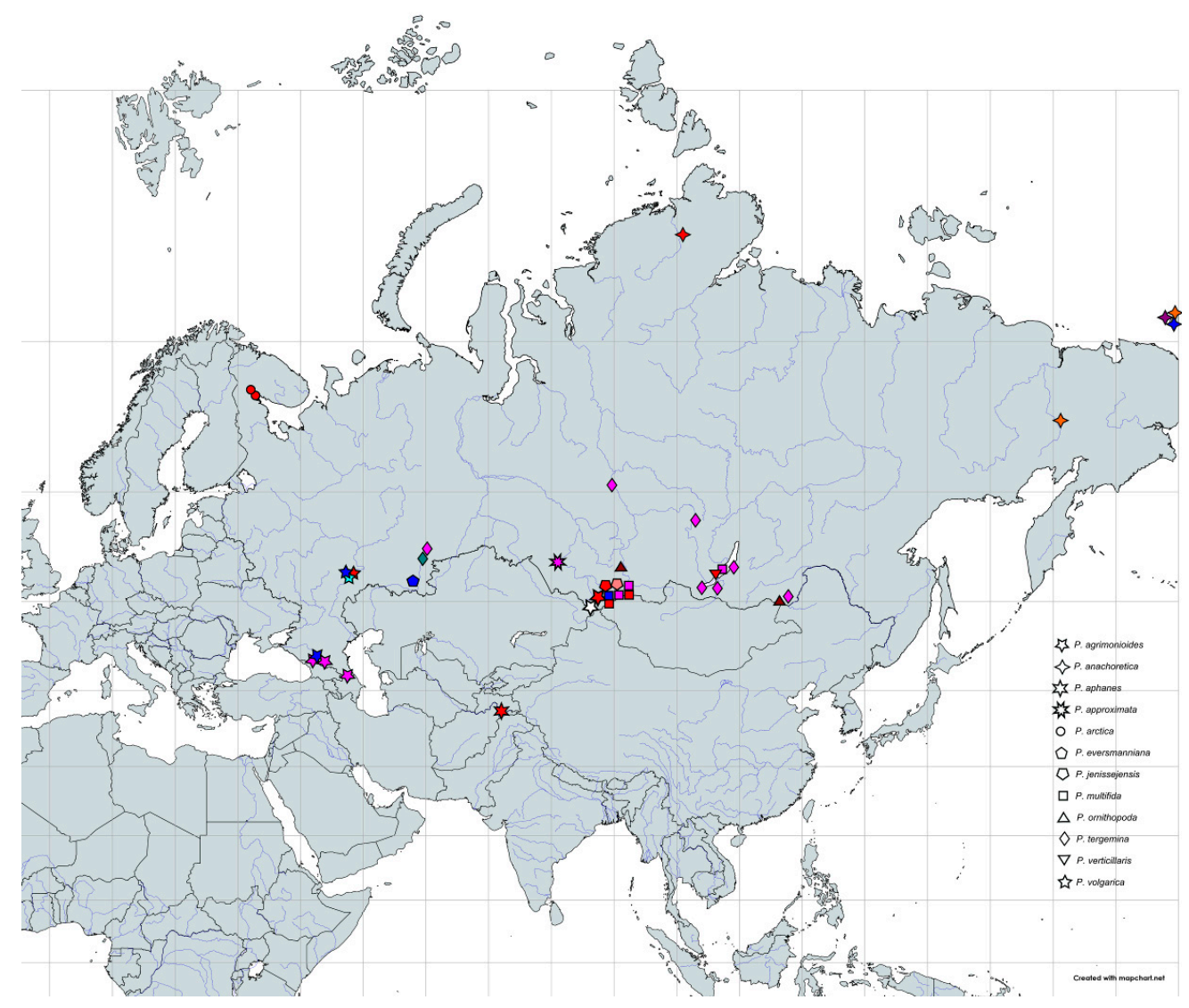

Figure 3. Geographical distribution of studied species and populations of Potentilla multifida agg. Colors of symbols follow Figure 1. Closely situated localities of the same species are lumped when represented by the same haplotype lineage. Localities of $P$. tergemina on railroads outside its natural range are not shown.

Internal haplotypes I and J are three and four mutational steps from haplotype G, respectively, and are found in two samples of P. tergemina, from a railway in Kiev (Ukraine) and a roadside plant in the Southeastern Urals, respectively.

Internal haplotype $\mathrm{K}$ is distanced from haplotype $\mathrm{J}$ by four mutational steps. It is central for the third group of haplotypes represented by tip haplotypes K1-K4 and a clade L-L1-L2. Haplotype K is characteristic of P. eversmanniana from the Southern Urals. However, it is also found in a sample of P. multifida from the Altai Mountains, a sample of P. anachoretica from Wrangel Island, and in four samples of $P$. volgarica from a single locality (a chalk hill near Novaya Yablonka) in Saratov Province. Tip haplotypes were found in solitary samples of P. volgarica (K1), P. eversmanniana (K2), P. multifida (K3), and P. agrimonioides (K4). The haplotypes of the lineage L-L1-L2 were exclusively found among samples of $P$. volgarica.

To root the network, we reduced the alignment, deleting all identical sequences among accessions of the same species, and analyzed it together with outgroup sequences with the maximal likelihood approach in raxmlGUI to reconstruct the species tree. The resulting tree is shown in Figure 1. Separate species are represented here by one to several accessions corresponding to the haplotypes revealed with TCS. Generally, the tree is congruent with the statistical parsimony-based haplotype network, yet the basal node is weakly supported and unresolved. The basal node forms a polytomy in which accessions from P. volgarica, P. nivea, P. jenissejensis, and P. agrimonioides corresponding to A haplotype sequences are positioned on zero (or very close to zero) length branches, thus matching the internal position of the A haplotype in the network (Figure 2). Eight more terminals of the basal polytomy are positioned on non-zero length branches, representing accessions of P. agrimonioides 
(from the Altai Mountains), P. anachoretica, P. aphanes, P. arctica, P. multifida, and P. volgarica. The basal polytomy also contains three highly (98\%) to moderately (81\%) supported clades corresponding to the three haplotype lineages derived from the internal haplotype $\mathrm{A}$ in the network. These are the clades of P. anachoretica (B and B1 haplotypes), P. jenissejensis (C and C1), and P. ornithopoda (E, F, and F1).

One of the lineages present in the network is not supported by the tree (D-D1). The major clade derived from the basal polytomy is weakly supported and includes all the remaining samples. It also forms a polytomy, and encompasses three samples of P. agrimonioides, P. multifida, and P. tergemina corresponding to the internal haplotype $G$ and positioned on zero length branches. Nine more terminals emerge from the polytomy on mostly short branches representing accessions of P. multifida, P. tergemina, P. approximata, and P. agrimonioides (the Caucasus). In addition to these, the polytomy contains two moderately supported clades, one encompassing two accessions of P. anachoretica and P. agrimonioides $(86 \%)$ and the other uniting the remaining samples $(79 \%)$. The latter clade includes a basal grade of two accessions of P. tergemina (representing internal haplotypes I and J of the network) and another polytomy uniting samples of P. eversmanniana, P. anachoretica, P. volgarica, P. multifida, and $P$. agrimonioides sharing internal haplotype $\mathrm{K}$ and all its derivatives.

\subsection{Nuclear ITS Data Analyses}

We managed to sequence the nuclear ribosomal ITS region from only a subset of samples sequenced for plastid IGS regions (Appendix A, Table A1). Readable parts of the ITS region varied in length from 390 to $521 \mathrm{bp}$. The alignment length was $529 \mathrm{bp}$, starting from the motif TTGTCGAA to the motif GAGGCT(T/-)CC, without any major gaps. Thirty-six sequences of the ingroup and five of the outgroup had 1-11 positions with ambiguities due to double peaks in electrophoregrams indicating probable heterozygosity of the samples. Altogether the alignment had 144 polymorphic sites, 71 of which had more than two variants. We did not clone sequences with ambiguities, but reconstructed possible ribotypes using the PHASE algorithm $[34,35]$ as realized in DNAsp. Though plants under study are most probably not diploids (see Introduction), we assumed them to be diploids for the purpose of further analyses. The alignment thus obtained had two sequences per individual, representing reconstructed alleles or ribotypes. We analyzed it using the ML approach in raxmlGUI. The resulting best tree was not fully resolved and many terminal branches were of zero length (Appendix A, Figure A1). The tree was converted to cladogram format for convenience of interpretation (Figure 4). Two different alleles of the same accession are designated with Figures 1 and 2 after a hyphen character in a terminal name. The ingroup forms a monophyletic clade with $100 \%$ bootstrap support, with both accessions of $P$. nivea included into the ingroup. Though deeper nodes of the tree are mostly unsupported, it is notable that conspecific accessions here form monophyletic groups with few exceptions. The basal grade includes both alleles of the first accession of $P$. nivea from the Caucasus and the first alleles of three accessions of P. anachoretica from Wrangel Island. Their counterparts with all the remaining accessions of this species from Wrangel Island constitute clade I. Clade II comprises two accessions of P. agrimonioides from the Caucasus representing both alleles of accession AGR2, and one of the alleles of accession AGR9. The second allele of this accession appears to be in the next (not numbered) clade of the grade together with an allele of the second accession of $P$. nivea. Clade III unites all the accessions of P. volgarica. This clade is weakly supported (53\%), yet most of its terminal subclades have moderate to high support. Clade IV unites most of the accessions of P. agrimonioides, both from the Caucasus and the Altai Mountains, and all the three accessions of P. jenissejensis, which form a separate subclade. Clade $\mathrm{V}$ unites accessions of several species and includes three major subclades. The subclade Va (unsupported) unites alleles of three accessions of P. eversmanniana; the subclade $\mathrm{Vb}$ (69\% support) unites three accessions of P. multifida and one accession of $P$. anachoretica (both alleles); the subclade Vc unites most of the accessions of P. arctica from the Kola Peninsula and one of the alleles of $P$. aphanes from Tadjikistan. Clade VI is the most heterogenous and includes accessions of P. tergemina, P. arctica, P. multifida, P. ornithopoda, and two alleles of P. aphanes and P. nivea with their counterparts in different clades. 


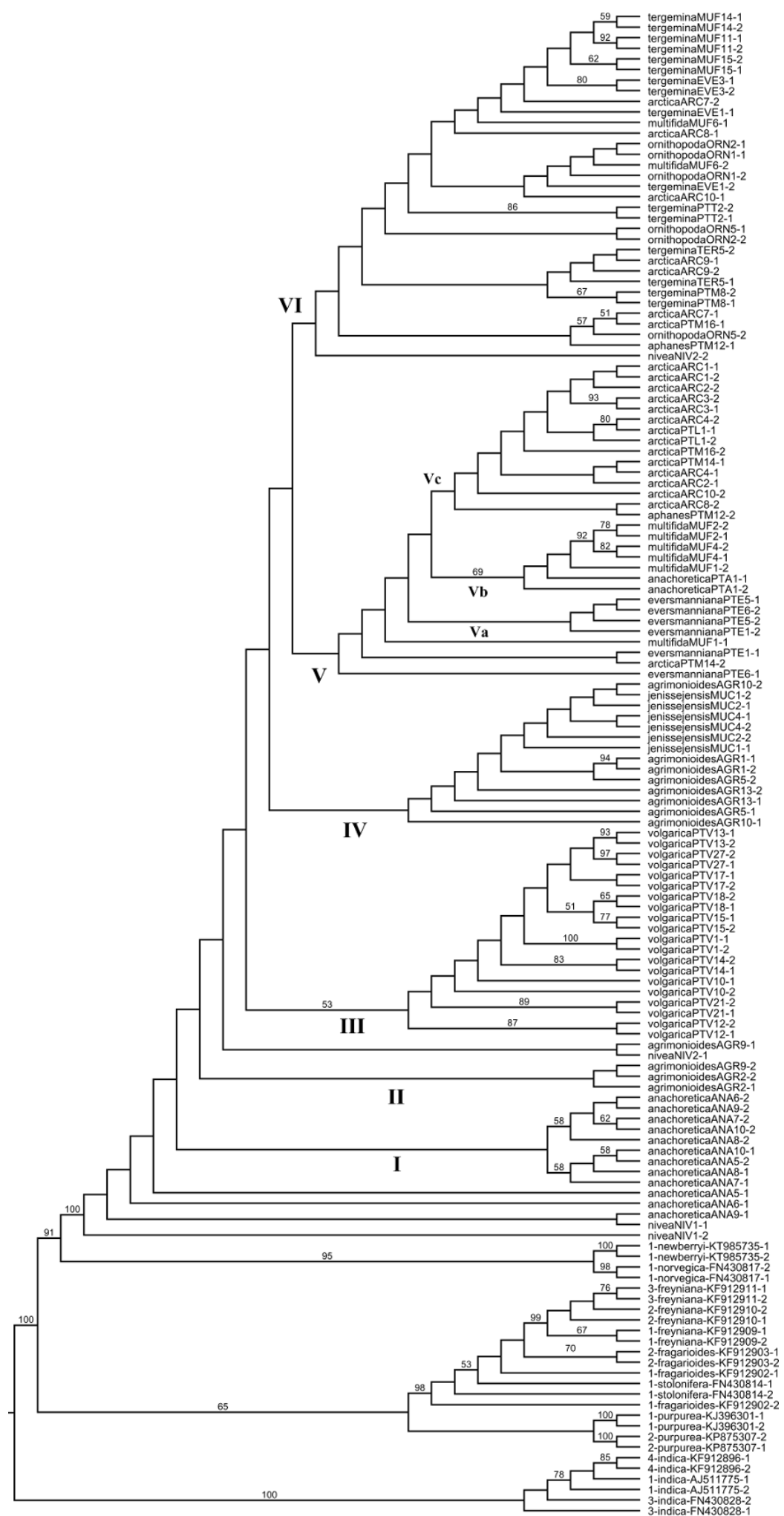

Figure 4. Maximum likelihood tree of Potentilla multifida agg. based on ITS data. Terminal names within the ingroup are followed by accession designations as in Table A1 and Figure 1 or Figure 2 indicating reconstructed alleles. Major clades corresponding to species are designated with Roman numerals. Bootstrap support higher than $50 \%$ is indicated above branches. 


\subsection{Potentilla volgarica and P. eversmanniana Population Structure Analyses}

We specifically analyzed populations of P. volgarica and P. eversmanniana to assess intra- and interpopulation genetic variability. Populations of $P$. volgarica appear to be extremely polymorphic in terms of plastid data and slightly less so in terms of nuclear ITS data, while populations of P. eversmanniana show low to zero variability in haplotype compositions (Table A1). The results of AMOVA analyses (Table 1) based on plastid sequences show most of the variability is between in-group populations (i.e., conspecific populations in our case). In the case of populations of $P$. volgarica taken separately, most of the variability is among local populations. The Mantel test demonstrated medium, but significant, correlation between genetic and geographical distances when both species are taken into consideration $(r=0.497, p=0.000)$. However, correlation between genetic and geographical distances is not significant $(\mathrm{r}=0.470, p=0.084)$ when only populations of $P$. volgarica are considered.

Table 1. AMOVA results for Potentilla volgarica and P. eversmanniana based on plastid DNA sequences. Fixation indices significant at $p<0.05$ are highlighted in bold.

\begin{tabular}{ccccc}
\hline Source of Variation & d.f. & $\begin{array}{c}\text { Variance } \\
\text { Components }\end{array}$ & $\begin{array}{c}\text { Percentage of } \\
\text { Variation }\end{array}$ & Fixation Indices \\
\hline & Potentilla volgarica vs. P. eversmanniana & & \\
\hline Among groups & 1 & $3.23474 \mathrm{Va}$ & 16.18 & FSC $=0.63879$ \\
\hline Among populations within groups & 7 & $10.70696 \mathrm{Vb}$ & 53.55 & FST $=\mathbf{0 . 6 9 7 2 2}$ \\
\hline Within populations & 37 & $6.05440 \mathrm{Vc}$ & 30.28 & FCT $\mathbf{0 . 1 6 1 7 7}$ \\
\hline Among populations & \multicolumn{4}{c}{ Potentilla volgarica } \\
\hline Within populations & 6 & $13.34836 \mathrm{Va}$ & 58.94 & FST $\mathbf{= 0 . 5 8 9 4 2}$ \\
\hline
\end{tabular}

Populations of $P$. volgarica are geographically structured at a local scale, haplotypes of the most derived plastid L clade occurring at the extreme south and north of the species area, whereas haplotypes of A and K clades occupy its central part (Figure 5).

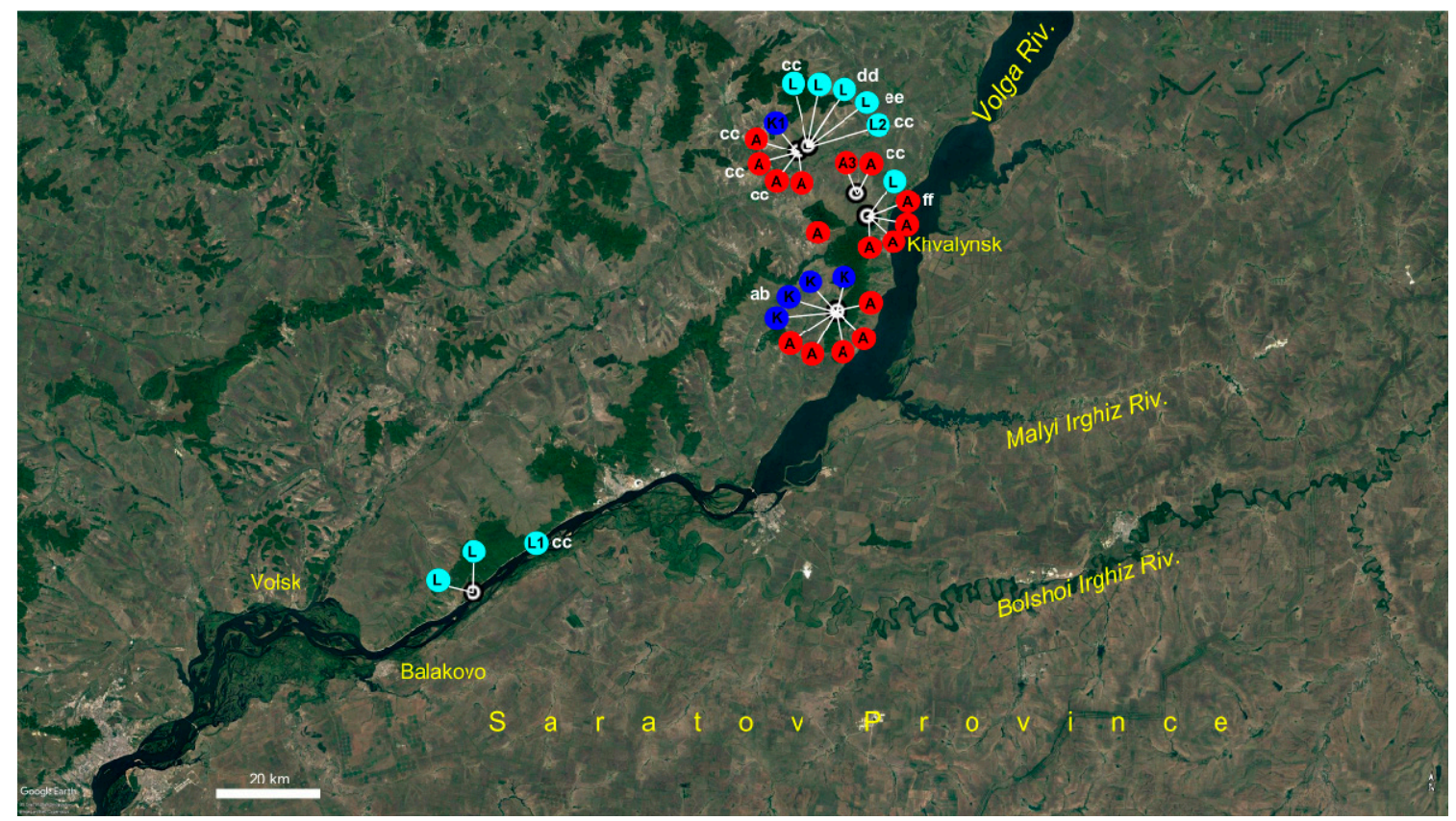

Figure 5. Plastid haplotypes and ITS genotypes geographical distribution in local populations of Potentilla multifida agg. Haplotype names follow Figure 2. ITS genotypes are designated with lower-case letters. 


\section{Discussion}

Our results suggest $P$. multifida agg. comprises a number of relatively young and incompletely genetically differentiated species widely distributed in Northern Eurasia. Plastid data suggest an incomplete lineage sorting (ILS) characteristic of the group as a whole, including $P$. nivea, traditionally referred to as a different section Niveae (Rydb.) A.Nelson. As it is clear from the plastid species tree (Figure 1), P. nivea shares the most basal haplotype A with a number of accessions of different species of P. multifida agg. The internal basal haplotype A was abundantly sampled from populations of $P$. volgarica only. In addition to these, we managed to reveal the haplotype A only in two accessions of P. agrimonioides and P. jenissejensis from the Altai Mountains in Altai and Tyva Republics, respectively, and in the above-mentioned accession of $P$. nivea from the Northern Caucasus. At the same time, its derivative tip haplotypes and clades are widely distributed over the whole range of the group. They are however absent from the Caucasus, the Urals, and forested areas of Southern Siberia, mostly occupied by populations bearing haplotypes of derivative $\mathrm{G}$ and $\mathrm{K}$ haplotype lineages (Figures 1 and 3). The haplotype A clade members appear to prevail in more harsh environments in the north and high mountains in the south. However, generally, no clear geographic pattern can be seen in the distribution of plastid haplotype groups with several instances of distantly-related tip haplotypes occurring in the same population. The absence of a clear distribution pattern supports incomplete lineage sorting and recurrent hybridization. The picture emerging from plastid data is that, much like European P. crantzii (Crantz) Beck ex Fritsch [26], the common ancestor of P. multifida agg. occupied a wide Eurasian periglacial range during cold periods of the Pleistocene period, and contracted to the modern disjunct distribution of P. multifida agg. species with climate warming. Similarly, considerable range expansions during the Last Glacial Maximum, and corresponding range contractions during the last interglacial and Holocene periods were discovered in Sibbaldia procumbens s.l. [36] and Rosa sericea s.l. complex [37].

Quite surprisingly, nuclear ITS demonstrates a different pattern, with most conspecific accessions, notably P. anachoretica, P. volgarica, and P. agrimonioides together with P. jenissejensis, P. eversmanniana, P. multifida, P. arctica, and P. tergemina, nesting within monophyletic clades (Figure 4). Several exceptions, where separate alleles of these species fall outside their main clades, appearing mostly in the clade VI representing all the accessions of $P$. tergemina, may indicate hybridization of these species with P. tergemina or its direct ancestor in the past. Notably, P. ornithopoda inferred alleles are dispersed among subclades of clade VI, while in the plastid tree its accessions form a monophyletic clade of haplotypes E, F, and F1. This may indicate a hybrid origin from unknown parents, probably unsampled in our study.

A special case represents P. volgarica. First of all, it is extremely genetically diverse as to plastid haplotypes. Most of the other species considered in this study possess few usually closely related haplotypes, or even are monomorphic, as P. arctica (A6), or nearly monomorphic, as P. eversmanniana $(\mathrm{K}, \mathrm{K} 2)$. P. volgarica is the only species represented by seven different haplotypes, A, A3, K, K1, L, L1, and L2, from two distant haplotype groups (A and K). Though just a subset of samples was sequenced for nrITS, all but one accession appeared to be homozygous, a situation reversed in other species where heterozygotes predominate. This also refers to its probably closest relative, P. eversmanniana from the Southwestern Urals. We sampled two local populations of this species (Table 1) and revealed them nearly monomorphic as to plastid haplotypes - all the plants possessed haplotype K, while its close derivative tip haplotype $\mathrm{K} 2$ was found in a singe plant. Contrary to that, all three specimens sequenced for ITS appeared to be heterozygotous. Moreover, populations of $P$. volgarica are mostly represented by homozygotes. We have studied seven local populations of $P$. volgarica from all localities of this species known so far (Figure 5). This mosaic pattern of plastid haplotype diversity together with predominant homozygosity of populations by ITS and results of AMOVA and Mantel test is suggestive of facultative apomixis in this species.

The unusual pattern of genetic diversity in P. volgarica may be explained by long persistence of the species in its current, extremely small distribution area, which probably behaves as a contemporary refugium. Ecologically, this species is restricted to steppe on hills with chalk outcrops. Potentilla volgarica 
populations, especially those in the central part of the area, deserve protection because they harbor most of the species' genetic polymorphism. Potentilla eversmanniana needs further study with larger sampling. However, the low genetic diversity observed in the present study suggests that it may be more vulnerable to habitat disturbance and climate change, than P. volgarica. Moreover, the plastid data suggest that it diverged from P. volgarica in the Pleistocene period, when this species probably had a wider distribution area.

\section{Materials and Methods}

\subsection{Taxon Sampling}

The plant material used in the present study was sampled from five local populations in the Saratovskaya Province of Russia (P. volgarica) and from two local populations in the Republic of Bashkortostan of Russia (P. ewersmanniana) in May-June 2019. Additional samples of both species, as well as $P$. arctica (a two population series in MHA and MW), P. anachoretica (a population series in MW and MHA), P. agrimonioides, P. aphanes Soják, P. jenissejensis (three specimens kept in MW under the name P. multicaulis), P. multifida, P. ornithopoda, P. approximata Bunge, P. tergemina (including several samples outside the natural range of the species collected at railroads in European Russia), and P. verticillaris were obtained from herbarium specimens kept at MHA, MW, and SARBG Herbaria. These materials were supplemented by sequences of distantly related species from other sections of Potentilla obtained from GenBank and used as an outgroup: P. freyniana Bornm. MK209638; P. hebiichigo Yonek. \& H.Ohashi MK144666; P. indica (Andrews) Th.Wolf KY420014, MK134678; P. purpurascens (S.Watson) Greene KY419979; P. purpurea Hook.f. KY419953, P. stolonifera Lehm. ex Ledeb. MK227179; P. tilingii (Regel) Greene KY420028. To root nuclear ITS trees we used following sequences acquired from GenBank: P. fragarioides L. KF912902, KF912903; P. freyniana KF912909, KF912910, KF912911; P. indica AY862574, KF912896, AJ511775, FN430828; P. newberryi A.Gray KT985735; P. norvegica L. FN430817; P. purpurea KP875307; P. stolonifera FN430814.

We determined the sampled plants using the keys to species of Potentilla in "Flora Europae Orientalis" [7], "Monographie der Gattung Potentilla" [1], J. Soják's critical papers [18-20], and V. Kurbatsky's [38] keys to the species of Potentilla of Asian Russia based on morphological characters. Two samples of P. eversmanniana from MW collected in Sverdlovsk Province (the Central Urals) were redetermined as P. tergemina, and three samples of $P$. multicaulis Bunge as P. jenissejensis. All the samples used for the analyses are listed in Appendix A, Table A1.

\subsection{Molecular Methods}

Total DNA was extracted from silica-dried leaf tissue and, in some cases, from herbarium samples using the NucleoSpin Plant DNA kit (Macherey Nagel, Germany) according to the manufacturer's protocol. For the molecular phylogenetic study we used three markers: nuclear ribosomal ITS1 and two plastid intergenic spacers (IGS), ndhC-trnV and $p s b A-t r n H$. For the amplification and subsequent sequencing of ITS region, NNC-18S10 (AGGAGAAGTCGTAACAA) and C26A (GTTTCTTTTCCTCCGCT) primers were used [39]. The plastid psbA-trnH IGS was amplified using trnH (CGCGCATGGTGGATTCACAATCC) and psbA (GTTATGCATGAACGTAATGCTC) primers, and the $n d h C-\operatorname{trn} V$ IGS was amplified with $n d h C$ (ATTAGAAATGYCCARAAAATATCAT) and trnV(UAC)x2 (GTCTACGGTTCGARTCCGTA) primers [40,41]. We chose these two regions after a pilot screening of several potentially variable plastid markers $[40,41]$ with a small subset of samples. All PCR products were directly sequenced in both directions with the same primers. Primers used for PCR were synthesized and purified in PAAG by Syntol Ltd. (Moscow, Russia). Double-stranded DNA templates were obtained by polymerase chain reaction (PCR). PCR reaction mixture $(20 \mu \mathrm{L})$ contained 1.5-2 ng of DNA, 5 pmol of each primer, $4 \mu \mathrm{L}$ of Ready-to-Use PCR Master mix 5× MasDDTaqMIX-2025, containing a "hot-start" SmarTaq DNA polymerase (Dialat Ltd., Moscow, Russia) and $13 \mu \mathrm{L}$ of deionized water. PCR reaction was performed on a MJ Research PTC220 DNA Engine Dyad Thermal Cycler 
(BioRad Laboratories, Foster City, CA, United States) under the following conditions. For ITS: $94{ }^{\circ} \mathrm{C}$ for $3 \mathrm{~min} ; 94^{\circ} \mathrm{C}$ for $20 \mathrm{~s}, 58^{\circ} \mathrm{C}$ for $30 \mathrm{~s}$, and $72{ }^{\circ} \mathrm{C}$ for $40 \mathrm{~s}\left(34\right.$ cycles); and $72{ }^{\circ} \mathrm{C}$ for $3 \mathrm{~min}$. For $n d h \mathrm{C}$ - $\operatorname{trn} V$ : $95^{\circ} \mathrm{C}$ for $3 \mathrm{~min} ; 95^{\circ} \mathrm{C}$ for $30 \mathrm{~s}, 57^{\circ} \mathrm{C}$ for $40 \mathrm{~s}$, and $60{ }^{\circ} \mathrm{C}$ for $1 \mathrm{~min} 20 \mathrm{~s}$ ( 35 cycles); $57{ }^{\circ} \mathrm{C}$ for $40 \mathrm{~s}, 60^{\circ} \mathrm{C}$ for $1 \mathrm{~min} 20 \mathrm{~s}$ ( 2 cycles). For $p s b A$-trnH: $95^{\circ} \mathrm{C}$ for $3 \mathrm{~min} ; 95^{\circ} \mathrm{C}$ for $30 \mathrm{~s}, 52,5{ }^{\circ} \mathrm{C}$ for $30 \mathrm{~s}$, and $72{ }^{\circ} \mathrm{C}$ for

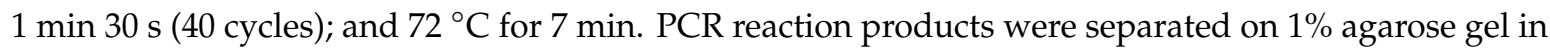
$0.5 \times \mathrm{TBE}$ buffer containing ethidium bromide and purified by precipitation in $0.125 \mathrm{M} / \mathrm{L}$ ammonium acetate solution in 70\% ethanol. DNA was sequenced on a 3730 DNA Analyzer (Applied Biosystems, Foster City, CA, United States) at the Genome Research Resource Center, Engelhardt Institute of Molecular Biology. All sequences were deposited in the GenBank database (www.ncbi.nlm.nih.gov); GenBank accession numbers of newly sequenced specimens are compiled in Table A1 (Appendix A).

\subsection{Sequence Editing and Alignment}

For the purposes of analysis, both plastid regions were concatenated. We were not able to sequence the ITS region for all samples (see Table A1); for many samples this region was sequenced incompletely. Sequences were aligned using MAFFT $[42,43]$ with the accurate strategy L-INS-i and modified manually using BioEdit 7.0 [44]. ITS and concatenated chloroplast regions were analyzed separately. Since the plastid alignment had multiple indels, some of which being dubiously aligned, we used the BMGE (Block Mapping and gathering with Entropy) v. 1.1. software [30] with the default -t option to trim the alignment to remove gaps and phylogenetically uninformative and homoplasious positions.

\subsection{Data Analyses}

Phylogenetic reconstruction was performed in RAxML ver. 8.2.10 using raxmlGUI 2.0 beta [45-48]. Bootstrap values are based on 100 replicates (Fast bootstrap option). The program searched for trees with the maximum likelihood approach under the GTRGAMMA model with parameters calculated by the program. Phylogenetic relationships among the cpDNA haplotypes were reconstructed using statistical parsimony analysis as implemented in TCS v1.2 [49] with alignment gaps treated as missing data. We edited the resulting trees in FigTree v.1.4.3 [50] and finally elaborated all the figures in InkScape v.0.48.2 (https://inkscape.org).

To root the trees we downloaded from GenBank eight complete chloroplast genomes of different species of Potentilla and used only two regions from these cp genomes, $n d h \mathrm{C}-\mathrm{trn} \mathrm{V}$ and $p s b \mathrm{~A}-\mathrm{trn \textrm {H }}$. Additionally, we sequenced two specimens of $P$. nivea as a possible close outgroup [14].

The programs DNAsp v.6 [51] and Arlequin v. 3.5.2.2. [52] were used to calculate several genetics parameters. For the geographical mapping of Potentilla haplotypes we used the Google Earth 7.3.2.5776 software.

Author Contributions: I.A.S. contributed to the field collection of samples, formal analyses of the data, and manuscript draft writing. A.V.F. contributed to the field collection of samples, all the laboratory work including DNA extraction, PCR, sequencing, and preliminary analyses of the data. O.V.S. contributed to preparation of the manuscript, creation of specifically critical review, commentary and revision at a pre-publication stage. G.F.S. contributed to obtaining necessary permissions to collect in Khvalynsky National Park, the indication of local populations of P. volgarica, and field collection of samples. All authors have read and agreed to the published version of the manuscript.

Funding: This research was funded by Russian Foundation for Basic Research, project 19-04-01308 and, partially, from Tsitsin Main Botanical Garden state assignment no. 19-119012390082-6.

Acknowledgments: The authors thank the curators of the Herbaria SARBG, MW, and MHA for permission to destructive sampling specimens; Alexander S. Kashin (Saratov State University Botanical Garden) for help in field studies; Keith Chamberlain (Cardiff University, UK) and Irina Belyaeva (Royal Botanic Gardens, Kew, UK) for improving the English grammar and style of the manuscript, and of the three anonymous reviewers for their critical reading of the manuscript which enabled us to improve it significantly.

Conflicts of Interest: The authors declare no conflict of interest. 


\section{Appendix A}

Table A1. Species, accessions, specimen vouchers, plastid haplotypes, and GenBank accession numbers of plastid and nuclear ITS sequences used in the study. Underlined ITS accession numbers indicate the presence of ambiguous positions in ITS sequences (putative heterozygotes).

\begin{tabular}{|c|c|c|c|c|c|}
\hline $\begin{array}{l}\text { Samples and } \\
\text { Accessions }\end{array}$ & Specimen Voucher & $\begin{array}{c}\text { Plastid } \\
\text { Haplotype }\end{array}$ & $n d h \mathrm{C}-t r n \mathrm{~V}$ & $p s b \mathrm{~A}-t r n \mathbf{H}$ & ITS \\
\hline $\begin{array}{l}\text { P. agrimonioides } \\
\text { (AGR1) }\end{array}$ & $\begin{array}{l}\text { [Russia] Karachay-Cherkessia, W spurs } \\
\text { of Mt. Elbrus, right slope of the } \\
\text { Biytik-Tyubyu Riv. basin, ca. } 5 \mathrm{~km} \\
\text { upstream the Kyukyurtlyu Riv. mouth, } \\
\text { meadow-steppe slope, } 4.08 .2009 \text {, A.S. } \\
\text { Zernov No. } 7269,43.411297^{\circ} \text { N, } \\
42.344777^{\circ} \text { E (MW) }\end{array}$ & G & MW046910 & MW046965 & MW042130 \\
\hline $\begin{array}{l}\text { P. agrimonioides } \\
\text { (AGR10) }\end{array}$ & $\begin{array}{l}\text { [Russia] Altai Republic, Kosh-Agachsky } \\
\text { distr., Saylyugem ridge, the } \\
\text { Chagan-Burgazy Riv. basin, middle } \\
\text { part of the left slope of the } \\
\text { Bayan-Chagan Riv. valley ca. } 5 \mathrm{~km} \\
\text { upstream its flow into the Karasu Riv. } \\
2690 \text { m alt., } 11.08 .1999 \text {, D.A. Petelin, } \\
\text { N.V. Fedotkina No. 99-462 (specimen 2), } \\
49.516667^{\circ} \text { N, } 88.766667^{\circ} \text { E (MW) }\end{array}$ & $\mathrm{D}$ & MW046906 & MW046961 & $\underline{\text { MW042127 }}$ \\
\hline $\begin{array}{l}\text { P. agrimonioides } \\
\text { (AGR11) }\end{array}$ & $\begin{array}{l}\text { [Russia] Altai Republic, Kosh-Agachsky } \\
\text { distr., Saylyugem ridge, the } \\
\text { Chagan-Burgazy Riv. basin, middle } \\
\text { part of the left slope of the } \\
\text { Bayan-Chagan Riv. valley ca. } 5 \mathrm{~km} \\
\text { upstream its flow into the Karasu Riv. } \\
2690 \mathrm{~m} \text { alt., } 11.08 .1999 \text {, D.A. Petelin, } \\
\text { N.V. Fedotkina No. } 99-462 \text { (specimen } 3 \text { ), } \\
49.516667^{\circ} \text { N, } 88.766667^{\circ} \text { E (MW) }\end{array}$ & D1 & MW046907 & MW046962 & - \\
\hline $\begin{array}{l}\text { P. agrimonioides } \\
\text { (AGR12) }\end{array}$ & $\begin{array}{l}\text { [Russia] Altai Republic, Kosh-Agachsky } \\
\text { distr., Chikhachev ridge, the } \\
\text { Bar-Burgazy Riv. valley, left shingle } \\
\text { bank of the river, alt. } 2075 \mathrm{~m}, 05.07 .1982, \\
\text { A. Maneev, A. Krasnikov, } 49.916667^{\circ} \mathrm{N}, \\
89.416667^{\circ} \mathrm{E}(\mathrm{MW})\end{array}$ & $\mathrm{D}$ & MW046908 & MW046963 & - \\
\hline $\begin{array}{l}\text { P. agrimonioides } \\
\text { (AGR13) }\end{array}$ & $\begin{array}{l}\text { [Russia] Altai Republic, Kosh-Agachsky } \\
\text { distr., Chikhachev ridge, the Tekelyu } \\
\text { Riv. valley (left tributary of the Bguzun } \\
\text { Riv.), rocks of the left bank, alt. } 2300 \mathrm{~m} \text {, } \\
27.07 .1981 \text {, A. Maneyev, A. Krasnikov } \\
\text { (left sample), } 50.083333^{\circ} \mathrm{N}, 89.416667^{\circ} \\
\text { E (MW) }\end{array}$ & A & MW046909 & MW046964 & $\underline{\text { MW042129 }}$ \\
\hline $\begin{array}{l}\text { P. agrimonioides } \\
\text { (AGR2) }\end{array}$ & $\begin{array}{l}\text { [Russia] Karachay-Cherkessia, } \\
\text { Karachaevsky distr., vicinity of } \\
\text { Verkhnyaya Mara vill., Mount } \\
\text { Kyokle-Bashi, S spurs, alt. ca. } 1800 \mathrm{~m} \text {, } \\
\text { meadow-steppe slope near summit, } \\
\text { 13.07.2009, A.S. Zernov, S.A. Senator No. } \\
\text { 7103, } 43.775^{\circ} \text { N, } 42.117778^{\circ} \text { E (MW) }\end{array}$ & K4 & MW046911 & MW046966 & $\underline{\text { MW042131 }}$ \\
\hline $\begin{array}{l}\text { P. agrimonioides } \\
\text { (AGR3) }\end{array}$ & $\begin{array}{l}\text { [Russia] Stavropol Territory, Elbrus } \\
\text { distr., village Uchkulan, upstream of } \\
\text { the Kuban Riv., mountain steppe, } 17 \text {. } \\
\text { 07.1967, T.A. Lezhankina, } 43.449018^{\circ} \text { N, } \\
42.088726^{\circ} \text { E (MW) }\end{array}$ & G & MW046912 & MW046967 & MW042132 \\
\hline $\begin{array}{l}\text { P. agrimonioides } \\
\text { (AGR4) }\end{array}$ & $\begin{array}{l}\text { [Russia] North Ossetian ASSR, the } \\
\text { Ardon Riv. basin, left slope of Alagir } \\
\text { gorge above Nuzal vill., dry stony } \\
\text { slopes, alt. } 1100 \mathrm{~m}, 18.05 .1977, \text { A.M. } \\
\text { Amirkhanov } 42.824758^{\circ} \text { N, } 44.019145^{\circ} \\
\text { E (MW) }\end{array}$ & G & MW046913 & MW046968 & MW042133 \\
\hline
\end{tabular}


Table A1. Cont.

\begin{tabular}{|c|c|c|c|c|c|}
\hline $\begin{array}{l}\text { Samples and } \\
\text { Accessions }\end{array}$ & Specimen Voucher & $\begin{array}{c}\text { Plastid } \\
\text { Haplotype }\end{array}$ & $n d h \mathrm{C}-t r n \mathrm{~V}$ & $p s b \mathrm{~A}-t r n \mathrm{H}$ & ITS \\
\hline $\begin{array}{l}\text { P. agrimonioides } \\
\text { (AGR5) }\end{array}$ & $\begin{array}{l}\text { [Russia] North Ossetian ASSR, the } \\
\text { Ardon Riv. basin, the Main Dividing } \\
\text { Ridge system, W slope of Tseyskiy } \\
\text { Ridge above Buron vill., left slope of } \\
\text { Alagir gorge, scree SE slopes, alt. } 1200 \\
\text { m, 23.05.1977, A.M. Amirkhanov } \\
42.794852^{\circ} \mathrm{N}, 44.02317^{\circ} \mathrm{E}(\mathrm{MW})\end{array}$ & G & MW046914 & MW046969 & $\underline{M W 042134}$ \\
\hline $\begin{array}{l}\text { P. agrimonioides } \\
\text { (AGR6) }\end{array}$ & $\begin{array}{c}\text { [Russia] North Ossetian ASSR, the } \\
\text { Ardon Riv. basin, the Main Dividing } \\
\text { Ridge system, W slope of Tseyskiy } \\
\text { Ridge above Buron vill., left slope of } \\
\text { Alagir gorge, scree SE slopes, alt. } 1250 \\
\text { m, } 23.05 .1977, \text { A.M. Amirkhanov } \\
42.794852^{\circ} \mathrm{N}, 44.002317^{\circ} \text { E (MW) (left } \\
\text { specimen) }\end{array}$ & G & MW046915 & MW046970 & MW042135 \\
\hline $\begin{array}{l}\text { P. agrimonioides } \\
\text { (AGR9) }\end{array}$ & $\begin{array}{l}\text { [Russia] Dagestan Republic, the } \\
\text { Mularchay Riv., shoals of the left river } \\
\text { bank, alt. } 2740-2500 \mathrm{~m}, 05.08 .1989 \text {, A.M. } \\
\text { Amirkhanov No. } 21,41.28661^{\circ} \mathrm{N}, \\
47.741299^{\circ} \mathrm{E} \text { (MW) }\end{array}$ & G & MW046917 & MW046972 & MW042136 \\
\hline $\begin{array}{l}\text { P. anachoretica } \\
\text { (ANA4) }\end{array}$ & $\begin{array}{c}\text { [Russia] Chukotka AR, Wrangel Island, } \\
\text { middle course of the Mamontovaya Riv. } \\
\text { (near inflow of Khrustalny and Vesely } \\
\text { streams), steppe meadow at Vesely } \\
\text { stream mouth, 04.07.2014, I.N. Pospelov, } \\
\text { E.B. Pospelova No. 14-109 (upper } \\
\text { specimen), } 71.175511^{\circ} \text { N, } 179.75655 \text { W } \\
(\mathrm{MW})\end{array}$ & H1 & MW046919 & MW046974 & - \\
\hline $\begin{array}{l}\text { P. anachoretica } \\
\text { (ANA5) }\end{array}$ & $\begin{array}{l}\text { [Russia] Chukotka AR, Wrangel Island, } \\
\text { middle course of the Mamontovaya Riv. } \\
\text { (near inflow of Khrustalny and Vesely } \\
\text { streams), steppe meadow at Vesely } \\
\text { stream mouth, 04.07.2014, I.N. Pospelov, } \\
\text { E.B. Pospelova No. 14-109 (lower } \\
\text { specimen), } 71.175511^{\circ} \text { N, } 179.75655 \text { W } \\
(\mathrm{MW})\end{array}$ & $\mathrm{H}$ & MW046920 & MW046975 & MW042138 \\
\hline $\begin{array}{l}\text { P. anachoretica } \\
\text { (ANA6) }\end{array}$ & $\begin{array}{l}\text { [Russia] Chukotka AR, Wrangel Island, } \\
\text { upstream of the Neizvestnaya Riv., the } \\
\text { northern 'Bobovaya gorka' area, tundra, } \\
\text { 12.07.2014, I.N. Pospelov, E.B. } \\
\text { Pospelova No. 14-049 (upper specimen) } \\
71.169347^{\circ} \text { N, } 179.434647 \text { W (MW) }\end{array}$ & $\mathrm{H}$ & MW046921 & MW046976 & MW042139 \\
\hline
\end{tabular}


Table A1. Cont.

\begin{tabular}{|c|c|c|c|c|c|}
\hline $\begin{array}{l}\text { Samples and } \\
\text { Accessions }\end{array}$ & Specimen Voucher & $\begin{array}{c}\text { Plastid } \\
\text { Haplotype }\end{array}$ & $n d h \mathrm{C}-t r n \mathrm{~V}$ & $p s b \mathrm{~A}-\operatorname{trn} \mathrm{H}$ & ITS \\
\hline $\begin{array}{l}\text { P. anachoretica } \\
\text { (ANA8) }\end{array}$ & $\begin{array}{l}\text { [Russia] Chukotka AR, Wrangel Island, } \\
\text { upstream of the Neizvestnaya Riv., the } \\
\text { northern 'Bobovaya gorka' area, } \\
\text { thinned meadow, 12.07.2014, I.N. } \\
\text { Pospelov, E.B. Pospelova No. 14-049 } \\
\text { (left specimen) 71.169931 N, } \\
179.435272 \mathrm{~W}(\mathrm{MW})\end{array}$ & B & MW046922 & MW046977 & MW042141 \\
\hline $\begin{array}{l}\text { P. anachoretica } \\
\text { (ANA9) }\end{array}$ & $\begin{array}{l}\text { [Russia] Chukotka AR, Wrangel Island, } \\
\text { middle course of the Mamontovaya Riv. } \\
\text { (near inflow of Khrustalny and Vesely } \\
\text { streams), steppe meadow at Vesely } \\
\text { stream mouth, 06.07.2014, I.N. Pospelov, } \\
\text { E.B. Pospelova No. 14-110 71.176561 } \\
\text { N, } 179.7578 \text { W (MW) }\end{array}$ & $\mathrm{H}$ & MW046923 & MW046978 & $\underline{\text { MW042142 }}$ \\
\hline $\begin{array}{c}\text { P. anachoretica } \\
\text { (PTA2) }\end{array}$ & $\begin{array}{l}\text { [Russia] Chukotka AR, Wrangel Island, } \\
\text { Somnitelnaya Bay, 19.07.1984, B.Yurtsev, } \\
70.979137^{\circ} \mathrm{N}, 179.463733 \mathrm{~W} \text { (MHA) }\end{array}$ & K & MN849359 & MN871335 & - \\
\hline $\begin{array}{l}\text { P. anachoretica } \\
\text { (PTM11) }\end{array}$ & $\begin{array}{l}\text { [Russia] Magadan Prov., Bilibinsky } \\
\text { distr., right bank of the Omolon Riv., } 18 \\
\text { km downstream of the Kedon Riv. } \\
\text { mouth, steppe slope, 05.07.1976, G.L. } \\
\text { Antropova, A.P. Khokhryakov, } \\
\text { 65.717199N, 159.079131E (MHA) }\end{array}$ & B1 & MN849377 & MN871353 & - \\
\hline $\begin{array}{c}\text { P. approximata } \\
\text { (PTM6) }\end{array}$ & $\begin{array}{l}\text { [Russia] Novosibirsk Prov., Ordynsky } \\
\text { distr., vicinity of Kirza vill., steppe } \\
\text { meadow, alt. } 200 \mathrm{~m}, 01.07 .1991, \text { I.M. } \\
\text { Krasnoborov No. NS56, } 54.12^{\circ} \mathrm{N}, \\
81.40^{\circ} \text { E (MHA) }\end{array}$ & G10 & MN849385 & MN871361 & - \\
\hline $\begin{array}{l}\text { P. arctica } \\
\text { (ARC1) }\end{array}$ & $\begin{array}{l}\text { [Russia] Murmansk Prov., Kandalaksha } \\
\text { distr., Tonnye Islands, Oleny } \\
\text { archipelago, sea-side meadow on rocks, } \\
22.06 .2016, \text { E.V. Kudr, K.A. Savina, } \\
67.11089^{\circ} \text { N, } 32.40611^{\circ} \text { E (MW) }\end{array}$ & A6 & MW046926 & MW046981 & MW042145 \\
\hline $\begin{array}{l}\text { P. arctica } \\
\text { (ARC10) }\end{array}$ & $\begin{array}{l}\text { [Russia] Murmansk Prov., Terskiy distr., } \\
\text { White Sea, Kandalaksha Gulf, Porya } \\
\text { Bay, Perunok island, southern rocky } \\
\text { cape, rocky meadow, 10.07.2011, M.N. } \\
\text { Kozhin No. M-1775, 66.77747 N } \\
33.62591^{\circ} \text { E (MW) }\end{array}$ & A6 & MW046924 & MW046979 & MW042143 \\
\hline $\begin{array}{l}\text { P. arctica } \\
\text { (ARC11) }\end{array}$ & $\begin{array}{l}\text { [Russia] Murmansk Prov., White Sea, } \\
\text { Porya Bay, Karbonatnaya Luda island, } \\
\text { 15.07.2008, M.N. Kozhin No. M-0623, } \\
66.73993^{\circ} \text { N, } 33.63885^{\circ} \text { E (MW) }\end{array}$ & A6 & MW046925 & MW046980 & - \\
\hline $\begin{array}{l}\text { P. arctica } \\
\text { (ARC2) }\end{array}$ & $\begin{array}{l}\text { [Russia] Murmansk Prov., Kandalaksha } \\
\text { distr., Kandalaksha Gulf of the White } \\
\text { Sea, Luven'gsky archipelago, } \\
\text { Golomyanny Vlasov island, cracked } \\
\text { sea-side rocks, } 16.08 .2017 \text {, E.I. Vuzman, } \\
67.07184^{\circ} \mathrm{N}, 32.72459^{\circ} \text { E (MW) }\end{array}$ & A6 & MW046927 & MW046982 & MW042146 \\
\hline
\end{tabular}


Table A1. Cont.

\begin{tabular}{|c|c|c|c|c|c|}
\hline $\begin{array}{l}\text { Samples and } \\
\text { Accessions }\end{array}$ & Specimen Voucher & $\begin{array}{c}\text { Plastid } \\
\text { Haplotype }\end{array}$ & $n d h \mathrm{C}-t r n \mathrm{~V}$ & $p s b \mathrm{~A}-\operatorname{trn} \mathrm{H}$ & ITS \\
\hline $\begin{array}{l}\text { P. anachoretica } \\
\text { (ANA8) }\end{array}$ & $\begin{array}{l}\text { [Russia] Chukotka AR, Wrangel Island, } \\
\text { upstream of the Neizvestnaya Riv., the } \\
\text { northern 'Bobovaya gorka' area, } \\
\text { thinned meadow, 12.07.2014, I.N. } \\
\text { Pospelov, E.B. Pospelova No. 14-049 } \\
\text { (left specimen) 71.169931 N, } \\
179.435272 \mathrm{~W}(\mathrm{MW})\end{array}$ & B & MW046922 & MW046977 & MW042141 \\
\hline $\begin{array}{l}\text { P. anachoretica } \\
\text { (ANA9) }\end{array}$ & $\begin{array}{l}\text { [Russia] Chukotka AR, Wrangel Island, } \\
\text { middle course of the Mamontovaya Riv. } \\
\text { (near inflow of Khrustalny and Vesely } \\
\text { streams), steppe meadow at Vesely } \\
\text { stream mouth, 06.07.2014, I.N. Pospelov, } \\
\text { E.B. Pospelova No. 14-110 71.176561 } \\
\text { N, } 179.7578 \text { W (MW) }\end{array}$ & $\mathrm{H}$ & MW046923 & MW046978 & $\underline{\text { MW042142 }}$ \\
\hline $\begin{array}{c}\text { P. anachoretica } \\
\text { (PTA2) }\end{array}$ & $\begin{array}{l}\text { [Russia] Chukotka AR, Wrangel Island, } \\
\text { Somnitelnaya Bay, 19.07.1984, B.Yurtsev, } \\
70.979137^{\circ} \mathrm{N}, 179.463733 \mathrm{~W} \text { (MHA) }\end{array}$ & K & MN849359 & MN871335 & - \\
\hline $\begin{array}{l}\text { P. anachoretica } \\
\text { (PTM11) }\end{array}$ & $\begin{array}{l}\text { [Russia] Magadan Prov., Bilibinsky } \\
\text { distr., right bank of the Omolon Riv., } 18 \\
\text { km downstream of the Kedon Riv. } \\
\text { mouth, steppe slope, 05.07.1976, G.L. } \\
\text { Antropova, A.P. Khokhryakov, } \\
\text { 65.717199N, 159.079131E (MHA) }\end{array}$ & B1 & MN849377 & MN871353 & - \\
\hline $\begin{array}{c}\text { P. approximata } \\
\text { (PTM6) }\end{array}$ & $\begin{array}{l}\text { [Russia] Novosibirsk Prov., Ordynsky } \\
\text { distr., vicinity of Kirza vill., steppe } \\
\text { meadow, alt. } 200 \mathrm{~m}, 01.07 .1991, \text { I.M. } \\
\text { Krasnoborov No. NS56, } 54.12^{\circ} \mathrm{N}, \\
81.40^{\circ} \text { E (MHA) }\end{array}$ & G10 & MN849385 & MN871361 & - \\
\hline $\begin{array}{l}\text { P. arctica } \\
\text { (ARC1) }\end{array}$ & $\begin{array}{l}\text { [Russia] Murmansk Prov., Kandalaksha } \\
\text { distr., Tonnye Islands, Oleny } \\
\text { archipelago, sea-side meadow on rocks, } \\
22.06 .2016, \text { E.V. Kudr, K.A. Savina, } \\
67.11089^{\circ} \text { N, } 32.40611^{\circ} \text { E (MW) }\end{array}$ & A6 & MW046926 & MW046981 & MW042145 \\
\hline $\begin{array}{l}\text { P. arctica } \\
\text { (ARC10) }\end{array}$ & $\begin{array}{l}\text { [Russia] Murmansk Prov., Terskiy distr., } \\
\text { White Sea, Kandalaksha Gulf, Porya } \\
\text { Bay, Perunok island, southern rocky } \\
\text { cape, rocky meadow, 10.07.2011, M.N. } \\
\text { Kozhin No. M-1775, 66.77747 N } \\
33.62591^{\circ} \text { E (MW) }\end{array}$ & A6 & MW046924 & MW046979 & MW042143 \\
\hline $\begin{array}{l}\text { P. arctica } \\
\text { (ARC11) }\end{array}$ & $\begin{array}{l}\text { [Russia] Murmansk Prov., White Sea, } \\
\text { Porya Bay, Karbonatnaya Luda island, } \\
\text { 15.07.2008, M.N. Kozhin No. M-0623, } \\
66.73993^{\circ} \text { N, } 33.63885^{\circ} \text { E (MW) }\end{array}$ & A6 & MW046925 & MW046980 & - \\
\hline $\begin{array}{l}\text { P. arctica } \\
\text { (ARC2) }\end{array}$ & $\begin{array}{l}\text { [Russia] Murmansk Prov., Kandalaksha } \\
\text { distr., Kandalaksha Gulf of the White } \\
\text { Sea, Luven'gsky archipelago, } \\
\text { Golomyanny Vlasov island, cracked } \\
\text { sea-side rocks, } 16.08 .2017 \text {, E.I. Vuzman, } \\
67.07184^{\circ} \mathrm{N}, 32.72459^{\circ} \text { E (MW) }\end{array}$ & A6 & MW046927 & MW046982 & MW042146 \\
\hline
\end{tabular}


Table A1. Cont.

\begin{tabular}{|c|c|c|c|c|c|}
\hline $\begin{array}{l}\text { Samples and } \\
\text { Accessions }\end{array}$ & Specimen Voucher & $\begin{array}{c}\text { Plastid } \\
\text { Haplotype }\end{array}$ & $n d h \mathrm{C}-t r n \mathrm{~V}$ & $p s b \mathrm{~A}-t r n \mathrm{H}$ & ITS \\
\hline $\begin{array}{l}\text { P. arctica } \\
\text { (ARC4) }\end{array}$ & $\begin{array}{l}\text { [Russia] Karelia, Loukhsky distr., } \\
\text { Vysoky Island, S shore, on rocks, } \\
\text { 4.07.2003, L.A. Abramova, P.A. Volkova, } \\
\text { K.A. Astafjev, } 66.574624^{\circ} \text { N, } 32.90934^{\circ} \text { E } \\
\qquad(\mathrm{MW})\end{array}$ & - & - & - & $\underline{\text { MW042148 }}$ \\
\hline $\begin{array}{l}\text { P. arctica } \\
\text { (ARC7) }\end{array}$ & $\begin{array}{l}\text { [Russia] Murmansk Prov., Terskiy distr., } \\
\text { White Sea, Kandalaksha Gulf, Porya } \\
\text { Bay, Krachny Baklysh Island, seashore } \\
\text { rocks, } 14.07 .2011 \text {, M.N. Kozhin No. } \\
\text { M-2075, 66.78828 N, 33.63157 E (MW) }\end{array}$ & A6 & MW046930 & MW046985 & $\underline{\text { MW042149 }}$ \\
\hline $\begin{array}{l}\text { P. arctica } \\
\text { (ARC8) }\end{array}$ & $\begin{array}{l}\text { [Russia] Murmansk Prov., Terskiy distr., } \\
\text { White Sea, Kandalaksha Gulf, Porya } \\
\text { Bay, Medvezhy Island, SE cape, rocks, } \\
\text { 21.07.2008, M.N. Kozhin No. M-0601, } \\
66,7^{\circ} \text { N, 33,6 E (MW) }\end{array}$ & A6 & MW046931 & MW046986 & $\underline{\text { MW042150 }}$ \\
\hline $\begin{array}{l}\text { P. arctica } \\
\text { (ARC9) }\end{array}$ & $\begin{array}{l}\text { [Russia] Murmansk Prov., Terskiy distr., } \\
\text { White Sea, Kandalaksha Gulf, Porya } \\
\text { Bay, Chayachya Luda Island, SW part, } \\
\text { rock crevices, } 4.08 .2011, \text { M.N. Kozhin } \\
\text { No. M-1858 (2 } 2^{\text {nd }} \text { sheet), } 66.78037^{\circ} \text { N, } \\
\quad 33.57952^{\circ} \text { E (MW) }\end{array}$ & A6 & MW046932 & MW046987 & MW042151 \\
\hline $\begin{array}{l}\text { P. arctica } \\
\text { (PTM15) }\end{array}$ & $\begin{array}{l}\text { [Russia] Murmansk Prov., Kandalaksha } \\
\text { distr., vicinity of Kovda vill., Sedlovaty } \\
\text { Island, seashore rocks, 27.07.2019, E.G. } \\
\text { Petrash, } 66.690052^{\circ} \text { N, 33.060953 E } \\
\text { (2nd sheet) (MHA) }\end{array}$ & A6 & MN849380 & MN871356 & - \\
\hline $\begin{array}{l}\text { P. arctica } \\
\text { (PTM16) }\end{array}$ & $\begin{array}{l}\text { [Russia] Murmansk Prov., Kandalaksha } \\
\text { distr., vicinity of Kovda vill., Sedlovaty } \\
\text { Island, seashore rocks, } 27.07 .2019 \text {, E.G. } \\
\text { Petrash, } 66.690052^{\circ} \text { N, 33.060953 E } \\
\text { (3rd sheet) (MHA) }\end{array}$ & A6 & MN849381 & MN871357 & MN872946 \\
\hline $\begin{array}{l}\text { P. arctica } \\
\text { (PTM17) }\end{array}$ & $\begin{array}{l}\text { [Russia] Murmansk Prov., Kandalaksha } \\
\text { distr., vicinity of Kovda vill., Sedlovaty } \\
\text { Island, seashore rocks, 27.07.2019, E.G. } \\
\text { Petrash, } 66.690052^{\circ} \text { N, } 33.060953^{\circ} \text { E (4th } \\
\text { sheet) (MHA) }\end{array}$ & A6 & MN849382 & MN871358 & - \\
\hline $\begin{array}{c}P . \\
\text { eversmanniana } \\
\text { (PTE1) }\end{array}$ & $\begin{array}{c}\text { [Russia] Rep. of Bashkortostan, } \\
\text { Zianchurinskii distr., Bashkirskaya } \\
\text { Chumaza vill., ca. } 500 \text { m downstream } \\
\text { the Bolshaya Samaza Rivulet, flat place } \\
\text { on a hill above the village, overgrazed } \\
\text { feather-grass steppe, } 26.05 .2019 \text {, I.A. } \\
\text { Schanzer, A.V. Fedorova No. } \\
\text { SH260519-13, } 51.943102^{\circ} \text { N, } 56.771153^{\circ} \\
\text { E (MHA) }\end{array}$ & K & MN849367 & MN871343 & MN872926 \\
\hline
\end{tabular}


Table A1. Cont.

\begin{tabular}{|c|c|c|c|c|c|}
\hline $\begin{array}{l}\text { Samples and } \\
\text { Accessions }\end{array}$ & Specimen Voucher & $\begin{array}{c}\text { Plastid } \\
\text { Haplotype }\end{array}$ & $n d h \mathrm{C}-t r n \mathrm{~V}$ & $p s b \mathrm{~A}-t r n \mathrm{H}$ & ITS \\
\hline $\begin{array}{c}P . \\
\text { eversmanniana } \\
\text { (PTE10) }\end{array}$ & $\begin{array}{l}\text { [Russia] Rep. of Bashkortostan, } \\
\text { Zianchurinskii distr., ca. } 2 \mathrm{~km} \mathrm{~S} \text { of } \\
\text { Bashkirskaya Chumaza vill., a small } \\
\text { valley between hills, stony slopes at a } \\
\text { hill summit, 27.05.2019, I.A. Schanzer, } \\
\text { A.V. Fedorova No. SH270519-02, 51. } \\
922852^{\circ} \text { N, 56. } 767177^{\circ} \text { E (MHA) }\end{array}$ & K & MN849360 & MN871336 & - \\
\hline $\begin{array}{c}P . \\
\text { eversmanniana } \\
\text { (PTE11) }\end{array}$ & $\begin{array}{l}\text { [Russia] Rep. of Bashkortostan, } \\
\text { Zianchurinskii distr., ca. } 2 \mathrm{~km} \mathrm{~S} \text { of } \\
\text { Bashkirskaya Chumaza vill., a small } \\
\text { valley between hills, stony slopes at a } \\
\text { hill summit, } 27.05 .2019 \text {, I.A. Schanzer, } \\
\text { A.V. Fedorova No. SH270519-03, 51. } \\
922852^{\circ} \text { N, 56. } 767177^{\circ} \text { E (MHA) }\end{array}$ & K & MN849361 & MN871337 & - \\
\hline $\begin{array}{c}P . \\
\text { eversmanniana } \\
\text { (PTE13) }\end{array}$ & $\begin{array}{l}\text { [Russia] Rep. of Bashkortostan, } \\
\text { Zianchurinskii distr., ca. } 2 \mathrm{~km} \mathrm{~S} \text { of } \\
\text { Bashkirskaya Chumaza vill., a small } \\
\text { valley between hills, stony slopes at a } \\
\text { hill summit, } 27.05 .2019 \text {, I.A. Schanzer, } \\
\text { A.V. Fedorova No. SH270519-05, } 51 \text {. } \\
922852^{\circ} \text { N, 56. } 767177^{\circ} \text { E (MHA) }\end{array}$ & K & MN849363 & MN871339 & - \\
\hline $\begin{array}{c}P . \\
\text { eversmanniana } \\
(\mathrm{PTE} 15)\end{array}$ & $\begin{array}{l}\text { [Russia] Rep. of Bashkortostan, } \\
\text { Zianchurinskii distr., ca. } 2 \mathrm{~km} \mathrm{~S} \mathrm{of} \\
\text { Bashkirskaya Chumaza vill., a small } \\
\text { valley between hills, stony slopes at a } \\
\text { hill summit, } 27.05 .2019 \text {, I.A. Schanzer, } \\
\text { A.V. Fedorova No. SH270519-07, } 51 . \\
922852^{\circ} \text { N, } 56.767177^{\circ} \text { E (MHA) }\end{array}$ & K & MN849365 & MN871341 & - \\
\hline $\begin{array}{c}P . \\
\text { eversmanniana } \\
\text { (PTE2) }\end{array}$ & $\begin{array}{c}\text { [Russia] Rep. of Bashkortostan, } \\
\text { Zianchurinskii distr., Bashkirskaya } \\
\text { Chumaza vill., ca. } 500 \text { m downstream } \\
\text { the Bolshaya Samaza Rivulet, flat place } \\
\text { on a hill above the village, overgrazed } \\
\text { feather-grass steppe, } 26.05 .2019 \text {, I.A. } \\
\text { Schanzer, A.V. Fedorova No. } \\
\text { SH260519-14, } 51.943102^{\circ} \text { N, } 56.771153^{\circ} \\
\text { E (MHA) }\end{array}$ & K & MN849368 & MN871344 & - \\
\hline $\begin{array}{c}P . \\
\text { eversmanniana } \\
\text { (PTE3) }\end{array}$ & $\begin{array}{c}\text { [Russia] Rep. of Bashkortostan, } \\
\text { Zianchurinskii distr., Bashkirskaya } \\
\text { Chumaza vill., ca. } 500 \mathrm{~m} \text { downstream } \\
\text { the Bolshaya Samaza Rivulet, flat place } \\
\text { on a hill above the village, overgrazed } \\
\text { feather-grass steppe, } 26.05 .2019, \text { I.A. } \\
\text { Schanzer, A.V. Fedorova No. } \\
\text { SH260519-15, } 51.943102^{\circ} \text { N, } 56.771153^{\circ} \\
\text { E (MHA) }\end{array}$ & K & MN849369 & MN871345 & - \\
\hline
\end{tabular}


Table A1. Cont.

\begin{tabular}{|c|c|c|c|c|c|}
\hline $\begin{array}{l}\text { Samples and } \\
\text { Accessions }\end{array}$ & Specimen Voucher & $\begin{array}{c}\text { Plastid } \\
\text { Haplotype }\end{array}$ & $n d h \mathrm{C}-t r n \mathrm{~V}$ & $p s b \mathbf{A}-t r n \mathbf{H}$ & ITS \\
\hline $\begin{array}{c}P . \\
\text { eversmanniana } \\
\text { (PTE5) }\end{array}$ & $\begin{array}{c}\text { [Russia] Rep. of Bashkortostan, } \\
\text { Zianchurinskii distr., Bashkirskaya } \\
\text { Chumaza vill., ca. } 500 \text { m downstream } \\
\text { the Bolshaya Samaza Rivulet, flat place } \\
\text { on a hill above the village, overgrazed } \\
\text { feather-grass steppe, } 26.05 .2019 \text {, I.A. } \\
\text { Schanzer, A.V. Fedorova No. } \\
\text { SH260519-17, } 51.943102^{\circ} \text { N, } 56.771153^{\circ} \\
\text { E (MHA) }\end{array}$ & K & MN849371 & MN871347 & $\underline{\mathrm{MN} 872930}$ \\
\hline $\begin{array}{c}P . \\
\text { eversmanniana } \\
(\text { PTE6) }\end{array}$ & 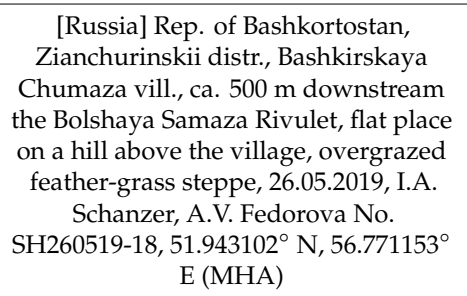 & $\mathrm{K}$ & MN849372 & MN871348 & MN872931 \\
\hline $\begin{array}{c}P . \\
\text { eversmanniana } \\
(\text { PTE7) }\end{array}$ & $\begin{array}{c}\text { [Russia] Rep. of Bashkortostan, } \\
\text { Zianchurinskii distr., Bashkirskaya } \\
\text { Chumaza vill., ca. } 500 \text { m downstream } \\
\text { the Bolshaya Samaza Rivulet, flat place } \\
\text { on a hill above the village, overgrazed } \\
\text { feather-grass steppe, } 26.05 .2019 \text {, I.A. } \\
\text { Schanzer, A.V. Fedorova No. } \\
\text { SH260519-26, 51.943102 }{ }^{\circ} \text { N, 56.771153 } \\
\text { E (MHA) }\end{array}$ & K & MN849373 & MN871349 & - \\
\hline $\begin{array}{c}P . \\
\text { eversmanniana } \\
\text { (PTE8) }\end{array}$ & $\begin{array}{c}\text { [Russia] Rep. of Bashkortostan, } \\
\text { Zianchurinskii distr., Bashkirskaya } \\
\text { Chumaza vill., ca. } 500 \text { m downstream } \\
\text { the Bolshaya Samaza Rivulet, flat place } \\
\text { on a hill above the village, overgrazed } \\
\text { feather-grass steppe, } 26.05 .2019 \text {, I.A. } \\
\text { Schanzer, A.V. Fedorova No. } \\
\text { SH260519-27, 51.943102 }{ }^{\circ} \text { N, } 56.771153^{\circ} \\
\text { E (MHA) }\end{array}$ & K & MN849374 & MN871350 & - \\
\hline $\begin{array}{c}P . \\
\text { eversmanniana } \\
\text { (PTE9) }\end{array}$ & 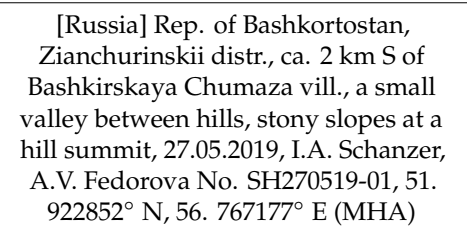 & K & MN849375 & MN871351 & - \\
\hline $\begin{array}{l}\text { P. jenissejensis } \\
\text { (MUC1) }\end{array}$ & $\begin{array}{l}\text { [Russia] Altai, Kosh-Agachsky distr., } \\
\text { Chikhachev ridge, the Bar-Burgazy Riv. } \\
\text { valley, thinned grassy slope in the flood } \\
\text { plain, alt. } 2100 \mathrm{~m}, 5.07 .1982, \mathrm{~A} . \\
\text { Maneyev, A. Krasnikov, } 49.916667^{\circ} \mathrm{N}, \\
89.416667^{\circ} \text { E (1st sheet) (MW) }\end{array}$ & C & MW046936 & MW046991 & MW042156 \\
\hline $\begin{array}{l}\text { P. jenissejensis } \\
\quad(\mathrm{MUC} 2)\end{array}$ & $\begin{array}{c}\text { [Russia] Tuvinskaya ASSR, } \\
\text { Mongun-Taiginsky distr., Chikhachev } \\
\text { ridge, the Ustu-Gimateh Riv. valley, } \\
\text { talus, } 11.08 .1980 \text {, A. Krasnikov, A. } \\
\text { Maneyev, N. Sidorenko (right } \\
\text { specimen), } 50.453164^{\circ} \mathrm{N}, 89.991742^{\circ} \mathrm{E} \\
(\mathrm{MW})\end{array}$ & A & MW046937 & MW046992 & MW042157 \\
\hline $\begin{array}{l}\text { P. jenissejensis } \\
\quad(\mathrm{MUC} 4)\end{array}$ & $\begin{array}{l}\text { [Russia] Altai, Kosh-Agachsky distr., } \\
\text { Chikhachev ridge, the Bar-Burgazy Riv. } \\
\text { valley, thinned grassy slope in the flood } \\
\text { plain, alt. } 2100 \mathrm{~m}, 5.07 .1982, \mathrm{~A} . \\
\text { Maneyev, A. Krasnikov, } 49.916667^{\circ} \mathrm{N}, \\
89.416667^{\circ} \text { E (2nd sheet) (MW) }\end{array}$ & $\mathrm{C} 1$ & MW046939 & MW046994 & $\underline{\text { MW042158 }}$ \\
\hline
\end{tabular}


Table A1. Cont.

\begin{tabular}{|c|c|c|c|c|c|}
\hline $\begin{array}{l}\text { Samples and } \\
\text { Accessions }\end{array}$ & Specimen Voucher & $\begin{array}{c}\text { Plastid } \\
\text { Haplotype }\end{array}$ & $n d h \mathrm{C}-t r n \mathrm{~V}$ & $p s b \mathrm{~A}-t r n \mathrm{H}$ & ITS \\
\hline $\begin{array}{l}\text { P. multifida } \\
\text { (MUF1) }\end{array}$ & $\begin{array}{l}\text { [Russia] Tuvinskaya ASSR, } \\
\text { Mongun-Taiginsky distr., Chikhachev } \\
\text { ridge, the Alty-Gimateh Riv. valley } 2 \\
\text { km upstream the mouth, meadow, } \\
\text { 04.08.1980, A. Krasnikov, A. Maneyev, V. } \\
\text { Shein, } 50.453164^{\circ} \text { N, } 89.991742^{\circ} \text { E (MW) }\end{array}$ & A1 & MW046944 & MW046999 & MW042162 \\
\hline $\begin{array}{l}\text { P. multifida } \\
\text { (MUF2) }\end{array}$ & $\begin{array}{c}\text { [Russia] Krasnoyarsky Territory, W } \\
\text { Sayan Mountains, Sayano-Shushensky } \\
\text { Nature Reserve, left bank of the B. Ura } \\
\text { Riv., meadow steppe, alt. } 1200 \mathrm{~m}, \\
\text { 12.08.1988, V. Kuvaev No. } 1214-18 \\
\text { (right specimen), } 51.990188^{\circ} \mathrm{N}, \\
91.842219^{\circ} \mathrm{E}(\mathrm{MW})\end{array}$ & G & MW046945 & MW047000 & MW042163 \\
\hline $\begin{array}{l}\text { P. multifida } \\
\text { (MUF4) }\end{array}$ & $\begin{array}{l}\text { [Russia] Tuvinskaya ASSR, } \\
\text { Mongun-Taiginsky distr., Chikhachev } \\
\text { ridge, the Alty-Gimateh Riv. valley } 2 \\
\text { km upstream the mouth, pebble bank, } \\
\text { 01.08.1980, A. Krasnikov, A. Maneyev, } \\
50.453164^{\circ} \mathrm{N}, 89.991742^{\circ} \mathrm{E}(\mathrm{MW})\end{array}$ & G & MW046946 & MW047001 & MW042164 \\
\hline $\begin{array}{l}\text { P. multifida } \\
\text { (MUF5) }\end{array}$ & $\begin{array}{l}\text { [Russia] Altai, Kosh-Agachsky distr., } \\
\text { Chikhachev ridge, the Baylugem Riv. } \\
\text { valley, alt. } 2270 \mathrm{~m}, 21.06 .1982, \mathrm{~A} . \\
\text { Maneyev, A. Krasnikov (upper } \\
\text { specimen) } 50.25^{\circ} \mathrm{N}, 89.33^{\circ} \mathrm{E}(\mathrm{MW})\end{array}$ & G & MW046947 & MW047002 & - \\
\hline $\begin{array}{l}\text { P. multifida } \\
\text { (MUF7) }\end{array}$ & $\begin{array}{l}\text { [Russia] Altai, Kosh-Agachsky distr., } \\
\text { Chikhachev ridge, the Baylugem Riv. } \\
\text { valley, alt. } 2270 \mathrm{~m}, 21.06 .1982, \mathrm{~A} . \\
\text { Maneyev, A. Krasnikov (lower } \\
\text { specimen) } 50.25^{\circ} \mathrm{N}, 89.33^{\circ} \mathrm{E} \text { (MW) }\end{array}$ & G2 & MW046949 & MW047004 & - \\
\hline $\begin{array}{l}\text { P. multifida } \\
\text { (PTM3) }\end{array}$ & $\begin{array}{l}\text { [Russia] Altai, Kosh-Agachsky distr., } \\
\text { the Tarhata Riv. valley, meadow on } \\
\text { river bank, alt. } 2150 \mathrm{~m}, 08.07 .1982, \mathrm{M} \text {. } \\
\text { Lomonosova, A. Vanyaev, } 49.45^{\circ} \mathrm{N}, \\
88.30^{\circ} \mathrm{E} \text { (MHA) }\end{array}$ & K & MN849383 & MN871359 & - \\
\hline $\begin{array}{l}\text { P. multifida } \\
\text { (PTM4) }\end{array}$ & $\begin{array}{l}\text { [Russia] Altai Mountains, vicinity of } \\
\text { Kosh-Agach, a quarry in } \\
\text { Leymus-steppe, alt. } 1770 \mathrm{~m}, 20.07 .1982, \\
\text { I. Krasnoborov, A. Krasnikov No. 1309, } \\
\quad 50.00^{\circ} \text { N, } 88.40^{\circ} \text { E (MHA) }\end{array}$ & $\mathrm{K} 3$ & MN849384 & MN871360 & - \\
\hline P. nivea (NIV1) & $\begin{array}{l}\text { [Russia] Karachay-Cherkessia, } \\
\text { Teberdinsky State Reserve, N spurs of } \\
\text { Malaya Khatipara Mt., stony slope, } \\
\text { 12.08.2006, A.S. Zernov No. 5524, } \\
43.438549^{\circ} \text { N, } 41.681227^{\circ} \text { E (MW) }\end{array}$ & A & MW046952 & MW047007 & MW042167 \\
\hline P. nivea (NIV2) & $\begin{array}{l}\text { [Russia] Karachay-Cherkessia, } \\
\text { Karachaevsky distr., S slope of Sadyrla } \\
\text { range, alt. ca. } 2900 \text {, talus, } 9.08 .2011 \text {, A.S. } \\
\text { Zernov, A.N. Filin No. } 7619,43.434741^{\circ} \\
\text { N, } 42.266179^{\circ} \text { E (MW) }\end{array}$ & A5 & MW046951 & MW047006 & MW042166 \\
\hline
\end{tabular}


Table A1. Cont.

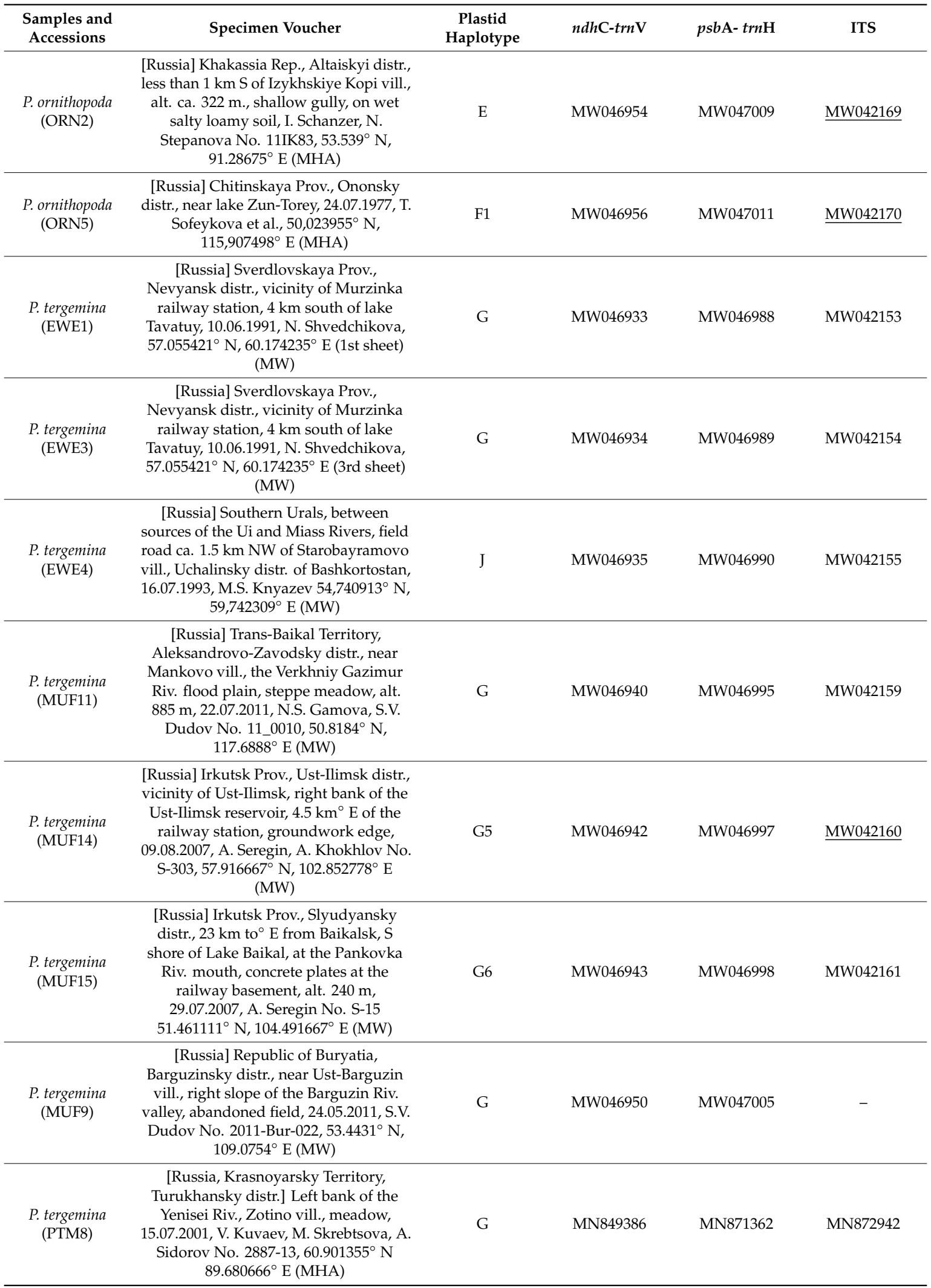


Table A1. Cont.

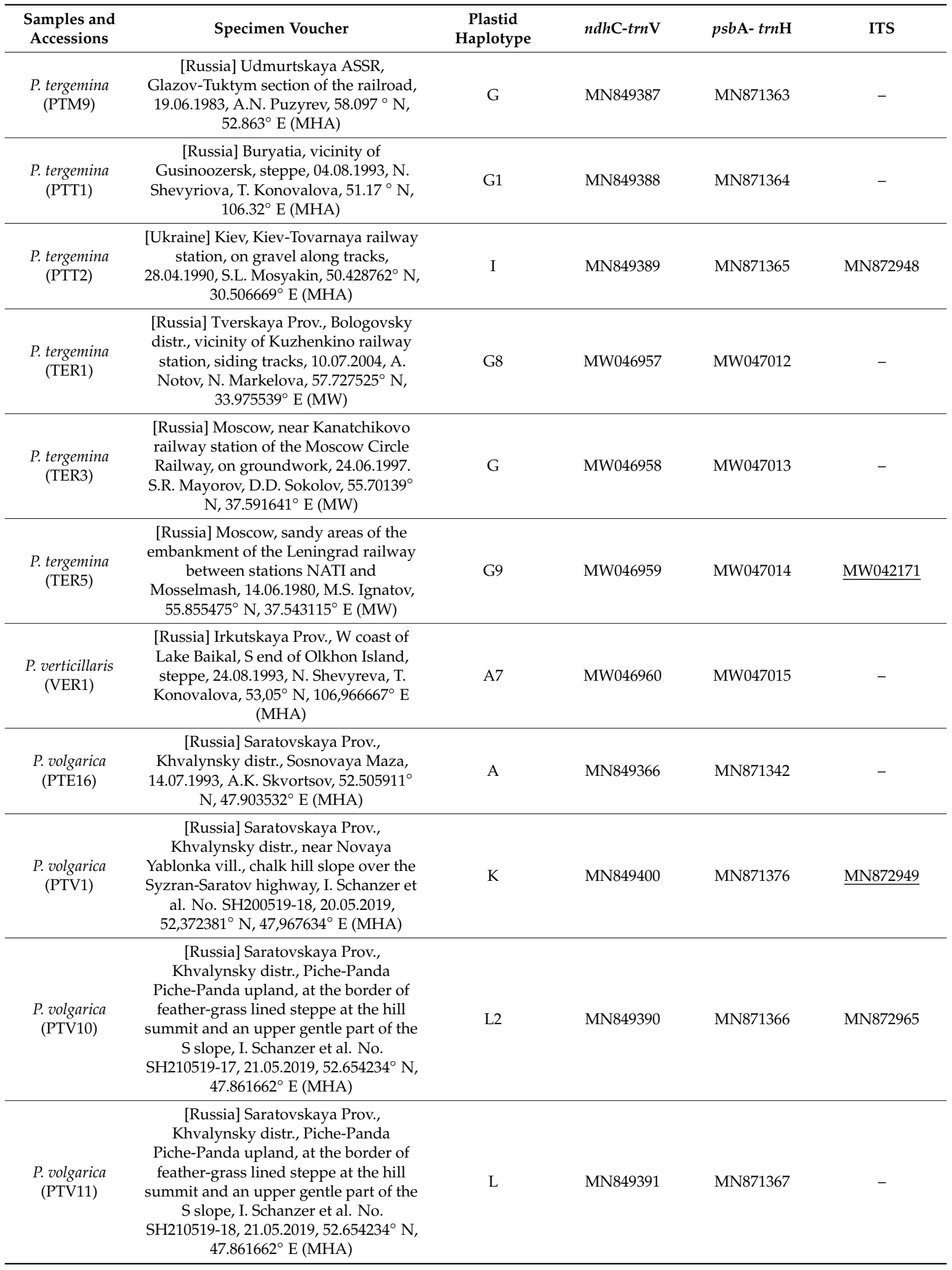


Table A1. Cont.

\begin{tabular}{|c|c|c|c|c|c|}
\hline $\begin{array}{l}\text { Samples and } \\
\text { Accessions }\end{array}$ & Specimen Voucher & $\begin{array}{c}\text { Plastid } \\
\text { Haplotype }\end{array}$ & $n d h \mathrm{C}-t r n \mathrm{~V}$ & $p s b \mathrm{~A}-t r n \mathrm{H}$ & ITS \\
\hline $\begin{array}{l}\text { P. volgarica } \\
\text { (PTV12) }\end{array}$ & $\begin{array}{c}\text { [Russia] Saratovskaya Prov., } \\
\text { Khvalynsky distr., Piche-Panda } \\
\text { Piche-Panda upland, at the border of } \\
\text { feather-grass lined steppe at the hill } \\
\text { summit and an upper gentle part of the } \\
\text { S slope, I. Schanzer et al. No. } \\
\text { SH210519-19, } 21.05 .2019,52.654234^{\circ} \mathrm{N} \\
47.861662^{\circ} \text { E (MHA) }\end{array}$ & $\mathrm{L}$ & MN849392 & MN871368 & MN872951 \\
\hline $\begin{array}{l}\text { P. volgarica } \\
\text { (PTV13) }\end{array}$ & $\begin{array}{c}\text { [Russia] Saratovskaya Prov., } \\
\text { Khvalynsky distr., Piche-Panda } \\
\text { Piche-Panda upland, at the border of } \\
\text { feather-grass lined steppe at the hill } \\
\text { summit and an upper gentle part of the } \\
\text { S slope, I. Schanzer et al. No. } \\
\text { SH210519-20, } 21.05 .2019,52.654234^{\circ} \mathrm{N}, \\
47.861662^{\circ} \text { E (MHA) }\end{array}$ & $\mathrm{L}$ & MN849393 & MN871369 & MN872952 \\
\hline $\begin{array}{l}\text { P. volgarica } \\
\text { (PTV14) }\end{array}$ & $\begin{array}{c}\text { [Russia] Saratovskaya Prov., } \\
\text { Khvalynsky distr., Piche-Panda } \\
\text { Piche-Panda upland, at the border of } \\
\text { feather-grass lined steppe at the hill } \\
\text { summit and an upper gentle part of the } \\
\text { S slope, I. Schanzer et al. No. } \\
\text { SH210519-21, } 21.05 .2019,52.654234^{\circ} \mathrm{N}, \\
47.861662^{\circ} \text { E (MHA) }\end{array}$ & $\mathrm{L}$ & MN849394 & MN871370 & MN872953 \\
\hline $\begin{array}{l}\text { P. volgarica } \\
\text { (PTV15) }\end{array}$ & $\begin{array}{l}\text { [Russia] Saratovskaya Prov., } \\
\text { Khvalynsky distr., Piche-Panda upland, } \\
\text { hills near Yeriomkino vill., low } \\
\text { deforestated chalky hill, } 21.05 .2019 \text {, I. } \\
\text { Schanzer, et al. No. SH210519-28, } \\
52.645109^{\circ} \mathrm{N}, 47.834526^{\circ} \mathrm{E}\end{array}$ & $\mathrm{K} 1$ & MN849395 & MN871371 & MN872954 \\
\hline $\begin{array}{l}\text { P. volgarica } \\
\text { (PTV17) }\end{array}$ & $\begin{array}{c}\text { [Russia] Saratovskaya Prov., } \\
\text { Khvalynsky distr., Piche-Panda upland, } \\
\text { hills near Yeriomkino vill., low } \\
\text { deforestated chalky hill, } 21.05 .2019, \text { I. } \\
\text { Schanzer, et al. No. SH210519-29, } \\
52.645109^{\circ} \text { N, } 47.834526^{\circ} \mathrm{E}\end{array}$ & A & MN849397 & MN871373 & MN872956 \\
\hline $\begin{array}{l}\text { P. volgarica } \\
\text { (PTV18) }\end{array}$ & $\begin{array}{l}\text { [Russia] Saratovskaya Prov., } \\
\text { Khvalynsky distr., Piche-Panda upland, } \\
\text { hills near Yeriomkino vill., low } \\
\text { deforestated chalky hill, } 21.05 .2019, \mathrm{I} . \\
\text { Schanzer, et al. No. SH210519-30, } \\
52.645109^{\circ} \mathrm{N}, 47.834526^{\circ} \mathrm{E}\end{array}$ & A & MN849398 & MN871374 & MN872957 \\
\hline $\begin{array}{l}\text { P. volgarica } \\
\text { (PTV19) }\end{array}$ & $\begin{array}{l}\text { [Russia] Saratovskaya Prov., } \\
\text { Khvalynsky distr., Piche-Panda upland, } \\
\text { hills near Yeriomkino vill., low } \\
\text { deforestated chalky hill, } 21.05 .2019, \mathrm{I} . \\
\text { Schanzer, et al. No. SH210519-31, } \\
52.645109^{\circ} \mathrm{N}, 47.834526^{\circ} \mathrm{E}\end{array}$ & A & MN849399 & MN871375 & - \\
\hline $\begin{array}{l}\text { P. volgarica } \\
\text { (PTV2) }\end{array}$ & $\begin{array}{l}\text { [Russia] Saratovskaya Prov., } \\
\text { Khvalynsky distr., near Novaya } \\
\text { Yablonka vill., chalk hill slope over the } \\
\text { Syzran-Saratov highway, I. Schanzer et } \\
\text { al. No. SH200519-19, 20.05.2019, } \\
52.372381^{\circ} \text { N, } 47.967634^{\circ} \text { E (MHA) }\end{array}$ & A & MN849411 & MN871387 & - \\
\hline
\end{tabular}


Table A1. Cont.

\begin{tabular}{|c|c|c|c|c|c|}
\hline $\begin{array}{l}\text { Samples and } \\
\text { Accessions }\end{array}$ & Specimen Voucher & $\begin{array}{c}\text { Plastid } \\
\text { Haplotype }\end{array}$ & $n d h \mathrm{C}-t r n \mathrm{~V}$ & $p s b \mathrm{~A}-\operatorname{trn} \mathrm{H}$ & ITS \\
\hline $\begin{array}{l}\text { P. volgarica } \\
\text { (PTV20) }\end{array}$ & $\begin{array}{c}\text { [Russia] Saratovskaya Prov., } \\
\text { Khvalynsky distr., } 4.5 \mathrm{~km} \text { NW of } \\
\text { Khvalynsk, chalk hills near a quarry N } \\
\text { of the Balakovo-Syzran highway. } \\
22.05 .2019 \text { I. Schanzer et al. No. } \\
\text { SH-220519-18, } 52.538878^{\circ} \mathrm{N}, 48.040852^{\circ} \\
\text { E (MHA) }\end{array}$ & A & MN849401 & MN871377 & - \\
\hline $\begin{array}{l}\text { P. volgarica } \\
\text { (PTV21) }\end{array}$ & $\begin{array}{c}\text { [Russia] Saratovskaya Prov., } \\
\text { Khvalynsky distr., } 4.5 \mathrm{~km} \text { NW of } \\
\text { Khvalynsk, chalk hills near a quarry N } \\
\text { of the Balakovo-Syzran highway. } \\
22.05 .2019 \text { I. Schanzer et al. No. } \\
\text { SH-220519-19, } 52.538878^{\circ} \mathrm{N}, 48.040852^{\circ} \\
\text { E (MHA) }\end{array}$ & A & MN849402 & MN871378 & MN872959 \\
\hline $\begin{array}{l}\text { P. volgarica } \\
\text { (PTV23) }\end{array}$ & $\begin{array}{c}\text { [Russia] Saratovskaya Prov., } \\
\text { Khvalynsky distr., } 4.5 \mathrm{~km} \text { NW of } \\
\text { Khvalynsk, chalk hills near a quarry N } \\
\text { of the Balakovo-Syzran highway. } \\
22.05 .2019 \text { I. Schanzer et al. No. } \\
\text { SH-220519-21, } 52.538878^{\circ} \mathrm{N}, 48.040852^{\circ} \\
\text { E (MHA) }\end{array}$ & A & MN849404 & MN871380 & - \\
\hline $\begin{array}{l}\text { P. volgarica } \\
\text { (PTV25) }\end{array}$ & $\begin{array}{c}\text { [Russia] Saratovskaya Prov., } \\
\text { Khvalynsky distr., } 4.5 \mathrm{~km} \text { NW of } \\
\text { Khvalynsk, chalk hills near a quarry N } \\
\text { of the Balakovo-Syzran highway. } \\
22.05 .2019 \text { I. Schanzer et al. No. } \\
\text { SH-220519-23, } 52.538878^{\circ} \mathrm{N}, 48.040852^{\circ} \\
\text { E (MHA) }\end{array}$ & A & MN849406 & MN871382 & - \\
\hline $\begin{array}{l}\text { P. volgarica } \\
\text { (PTV26) }\end{array}$ & $\begin{array}{l}\text { [Russia] Saratovskaya Prov., } \\
\text { Khvalynsky distr., chalk hills near a } \\
\text { road to Popovka, } 16.05 .1983, \text { L.H., } \\
52.576915^{\circ} \mathrm{N}, 48.006993^{\circ} \mathrm{E}(1 \mathrm{st} \\
\text { specimen) (SARBG 1498) }\end{array}$ & A3 & MN849407 & MN871383 & - \\
\hline $\begin{array}{l}\text { P. volgarica } \\
\text { (PTV27) }\end{array}$ & $\begin{array}{l}\text { [Russia] Saratovskaya Prov., } \\
\text { Khvalynsky distr., chalk hills near a } \\
\text { road to Popovka, } 16.05 .1983, \text { L.H., } \\
52.576915^{\circ} \mathrm{N}, 48.006993^{\circ} \mathrm{E}(2 \mathrm{nd} \\
\text { specimen) (SARBG 1498) }\end{array}$ & A & MN849408 & MN871384 & MN872962 \\
\hline $\begin{array}{l}\text { P. volgarica } \\
\text { (PTV28) }\end{array}$ & $\begin{array}{l}\text { [Russia] Saratovskaya Prov., } \\
\text { Khvalynsky distr., } 3-4 \text { km N of } \\
\text { Voskresensk, chalk outcrops of the bank } \\
\text { of the Volga Riv., } 25.06 .1988, \text { E.A. } \\
\text { Kireev, } 51.852827^{\circ} \mathrm{N}, 46.991139^{\circ} \text { E (1st } \\
\text { specimen) (SARBG 1499) }\end{array}$ & $\mathrm{L}$ & MN849409 & MN871385 & - \\
\hline
\end{tabular}


Table A1. Cont.

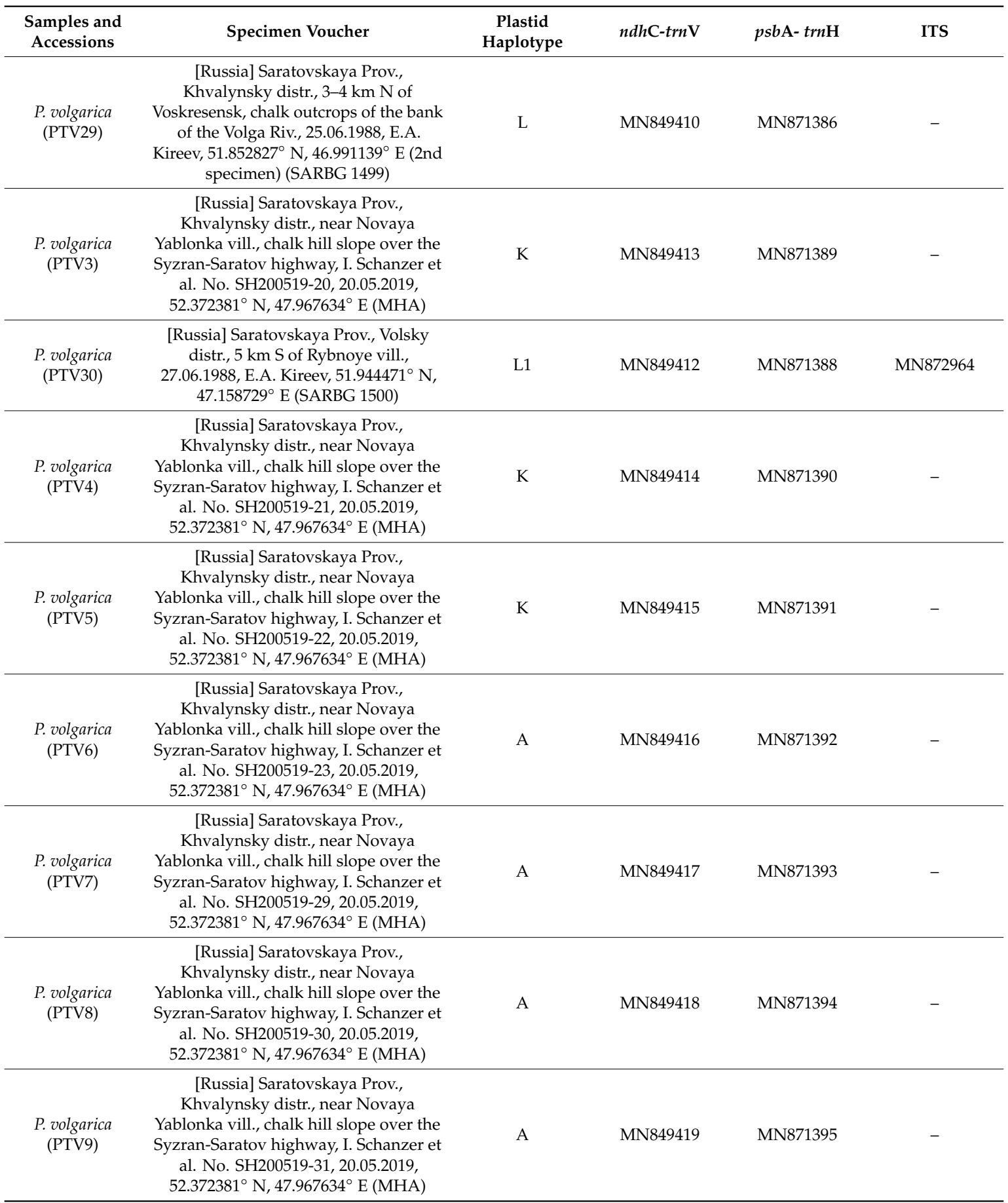




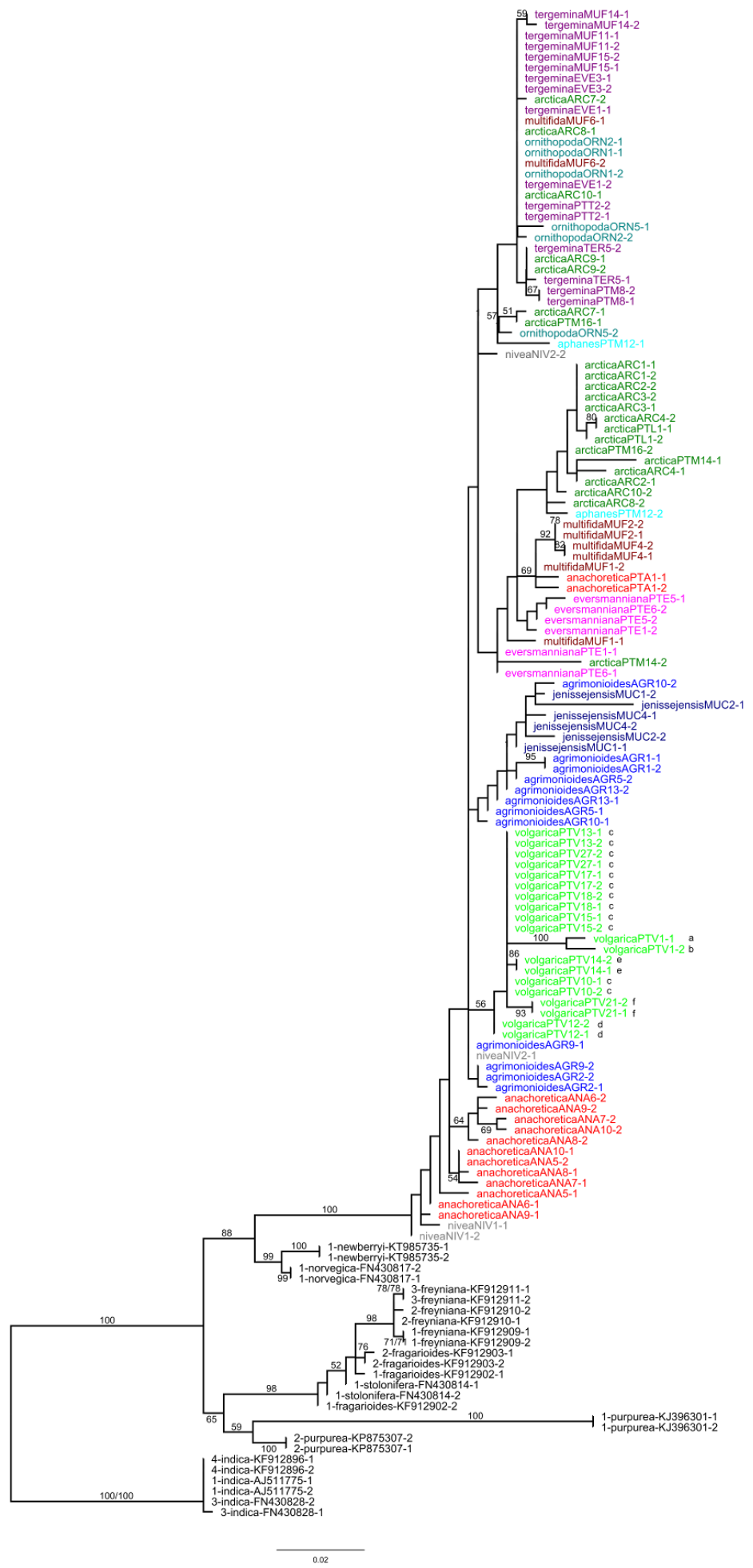

Figure A1. Maximum likelihood tree of Potentilla multifida agg. based on ITS data. Terminal names within the ingroup are followed by accession designations as in Table A1 and Figure 1 or Figure 2 indicating reconstructed alleles. Lower-case letters after $P$. volgarica terminals indicate ribotypes of this species. Different species are highlighted with different colors. 


\section{References}

1. Wolf, T. Monographie der Gattung. Potentilla. Bibl. Bot. 1908, 71, 1-715.

2. Dobeš, C.; Paule, J. A comprehensive chloroplast DNA-based phylogeny of the genus Potentilla (Rosaceae): Implications for its geographic origin, phylogeography and generic circumscription Mol. Phylogenet. Evol. 2010, 56, 156-175. [CrossRef] [PubMed]

3. Persson, N.L.; Toresen, I.; Andersen, H.L.; Smedmark, J.E.E.; Eriksson, T. Detecting destabilizing species in the phylogenetic backbone of Potentilla (Rosaceae) using low-copy nuclear markers. AoB Plants 2020, 12, plaa017. [CrossRef] [PubMed]

4. Müntzing, A.; Müntzing, G. Some new results concerning apomixis, sexuality and polymorphism in Potentilla Bot. Not. 1941, 94, 237-278.

5. Asker, S. Apomixis and sexuality in the Potentilla argentea complex. Hereditas 1970, 66, 127-144. [CrossRef]

6. Goswami, A.D.; Matfield, B. Pseudogamy in the genus Potentilla L. New Phytol. 1974, 73, $1243-1247$. [CrossRef]

7. Kamelin, R.V. Potentilla L. Flora Europae Orientalis; Tzvelev, N.N., Ed.; Mir i Semia: Petropoli, Russia, 2001; Volume 10, pp. 394-452.

8. Soják, J. Copies of seven species and twenty hybrids of Potentilla (Rosaceae) obtained through experimental hybridization. Notes on Potentilla XXVI. Thaiszia-J. Bot. 2012, 22, 33-48.

9. Töpel, M.; Lundberg, M.; Eriksson, T.; Eriksen, B. Molecular data and ploidal levels indicate several putative allopolyploidization events in the genus Potentilla (Rosaceae). PLoS Curr. Tree Life 2011, 18, 1. [CrossRef]

10. Nardi, F.D.; Dobeš, C.; Müller, D.; Grasegger, T.; Myllynen, T.; Alonso-Marcos, H.; Tribsch, A. Sexual intraspecific recombination but not de novo origin governs the genesis of new apomictic genotypes in Potentilla puberula (Rosaceae). Taxon 2018, 67, 1108-1131. [CrossRef]

11. Eriksson, T.; Donoghue, M.J.; Hibbs, M.S. Phylogenetic analysis of Potentilla using DNA sequences of nuclear ribosomal internal transcribed spacers (ITS), and implications for the classification of Rosoideae (Rosaceae). Plant Syst. Evol. 1998, 211, 155-179. [CrossRef]

12. Eriksson, T.; Hibbs, M.S.; Yoder, A.D.; Delwiche, C.F.; Donoghue, M.J. The phylogeny of Rosoideae (Rosaceae) based on sequences of the internal transcribed spacers (ITS) of nuclear ribosomal DNA and the trnL/F region of chloroplast DNA. Int. J. Plant Sci. 2003, 164, 197-211. [CrossRef]

13. Paule, J. Evolutionary Patterns and Processes in the Genus Potentilla L. (Rosaceae). Doctoral Dissertation, University of Heidelberg, Heidelberg, Germany, 23 July 2010.

14. Faghir, M.B.; Attar, F.; Farazmand, A.; Kazempour Osaloo, S. Phylogeny of the genus Potentilla (Rosaceae) in Iran based on nrDNA ITS and cpDNA trnL-F sequences with a focus on leaf and style characters' evolution. Turk. J. Bot. 2014, 38, 417-429. [CrossRef]

15. Feng, T.; Moore, M.J.; Yan, M.-H.; Sun, Y.-X.; Zhang, H.-J.; Meng, A.-P.; Li, X.-D.; Jian, S.-G.; Li, J.-Q.; Wang, H.-C. Phylogenetic study of the tribe Potentilleae (Rosaceae), with further insight into the disintegration of Sibbaldia. J. Sytematics Evol. 2017, 55, 177-191. [CrossRef]

16. Kurbatsky, V. Notes about genus Potentilla L. in the flora of Siberia. Turczaninowia 1999, 2, 10-18.

17. Li, C.-L.; Ikeda, H.; Ohba, H. Potentilla Linnaeus. In Flora of China; Wu, Z.Y., Raven, P.H., Hong, D.Y., Eds.; Science Press: Beijing, China; Missouri Botanical Garden Press: St. Louis, MO, USA, 2003; Volume 9, pp. 291-327.

18. Soják, J. Potentilla L. (Rosaceae) and related genera in the former USSR (identification key, checklist and figures). Notes on Potentilla XVI. Bot. Jahrb. Syst. 2004, 125, 253-340. [CrossRef]

19. Soják, J. Potentilla L. s.l. (Rosaceae) in Flora Europae Orientalis (Notes on Potentilla XVIII). Candollea 2005, 60, 59-78.

20. Soják, J. Potentilla L. (Rosaceae) in the former USSR; second part: Comments. Notes on Potentilla XXIV. Feddes Reper. 2009, 120, 185-217. [CrossRef]

21. Kechaykin, A.A.; Shmakov, A.I. A system of subtribe Potentillinae J. Presl (Rosaceae Juss.) Turczaninowia 2016, 19, 114-128. [CrossRef]

22. Walter, K.S.; Gillett, H.J. (Eds.) 1997 IUCN Red List of Threatened Plants; Compiled by the World Conservation Monitoring Centre; IUCN-The World Conservation Union: Gland, Switzerland; Cambridge, UK, 1998; pp. 494-495. 
23. Kamelin, R.V. Potentilla eversmanniana Fisch. ex Claus; Potentilla volgarica Juz. In Red Data Book of Russian Federation (Plants and, Fungi); Trutnev, Y.P., Gizatulin, R.R., Mitvol, O.L., Amirkhanov, A.M., Kamelin, R.V., Bardunov, L.V., Novikov, V.S., Orlov, V.A., Stepanitsky, V.B., Belanovich, D.M., et al., Eds.; KMK Press: Moscow, Russia, 2008; pp. 495-498.

24. Paule, J.; Scherbantin, A.; Dobeš, C. Implications of hybridisation and cytotypic differentiation in speciation assessed by AFLP and plastid haplotypes-A case study of Potentilla alpicola La Soie. BMC Evol. Biol. 2012, 12, 132. [CrossRef]

25. Dobeš, C.; Rossa, J.; Paule, J.; Hülber, K. Morphology, DNA-molecular variation, karyology, ecogeography, and phytosociology suggest allopatric differentiation and species rank for Potentilla rigoana (Rosaceae). Taxon 2013, 62, 733-745. [CrossRef]

26. Paule, J.; Kolář, F.; Dobeš, C. Arctic-alpine and serpentine differentiation in polyploid Potentilla crantzii. Preslia 2015, 87, 195-215.

27. Urgamal, M.; Oyuntsetseg, B.; Gundegmaa, V.; Munkh-Erdene, T.; Solongo, K. Additions to the vascular flora of Mongolia-III (Since the "Conspectus of the vascular plants of Mongolia 2014"). Proc. Mong. Acad. Sci. 2016, 56, 32-38. [CrossRef]

28. IPCN. Index to Plant Chromosome Numbers. In IPCN Database; Goldblatt, P., Johnson, D.E., Eds.; Missouri Botanical Garden: St. Louis, MO, USA, 1979; Available online: www.tropicos.org/project/ipcn (accessed on 30 September 2020).

29. Kechaykin, A.A.; Skaptsov, M.V.; Smirnov, S.V.; Kutsev, M.G.; Shmakov, A.I. Study of genome size representatives of the genus Potentilla L. (Rosaceae Juss.). Biol. Bull. Bogdan Chmelnitskiy Melitopol State Pedagog. Univ. 2016, 6, 229-233. [CrossRef]

30. Criscuolo, A.; Gribaldo, S. BMGE (block mapping and gathering with entropy): A new software for selection of phylogenetic informative regions from multiple sequence alignments. BMC Evol. Biol. 2010, 10, 210. [CrossRef] [PubMed]

31. Jacob, S.S.; Blattner, F.R. A plastid genealogy of Hordeum (Poaceae): Long-term persisting haplotypes, incomplete lineage sorting, regional extinction, and the consequences for phylogenetic inference. Mol. Biol. Evol. 2006, 23, 1602-1612. [CrossRef] [PubMed]

32. Gurushidze, M.; Fritsch, R.M.; Blattner, F.R. Species-level phylogeny of Allium subgenus Melanocrommyum: Incomplete lineage sorting, hybridization and trnF gene duplication. Taxon 2010, 59, 829-840. [CrossRef]

33. Templeton, A.R.; Crandall, K.A. Empirical tests of some predictions from coalescent theory with applications to intraspecific phylogeny reconstruction. Genetics 1993, 134, 959-969.

34. Stephens, M.; Smith, N.; Donelly, P. A new statistical method for haplotype reconstruction from population data. Am. J. Hum. Genet. 2001, 68, 978-989. [CrossRef]

35. Stephens, M.; Donelly, P. A comparison of bayesian methods for haplotype reconstruction from population genotype data. Am. J. Hum. Genet. 2003, 73, 1162-1169. [CrossRef]

36. Zhang, H.J.; Feng, T.; Landis, J.B.; Deng, T.; Zhang, X.; Meng, A.P.; Sun, H.; Wang, H.C.; Sun, Y.X. Molecular phylogeography and ecological niche modeling of Sibbaldia procumbens s.l. (Rosaceae). Front. Genet. 2019, 10, 201. [CrossRef]

37. Gao, Y.D.; Zhang, Y.; Gao, X.F.; Zhu, Z.M. Pleistocene glaciations, demographic expansion and subsequent isolation promoted morphological heterogeneity: A phylogeographic study of the alpine Rosa sericea complex (Rosaceae). Sci. Rep. 2015, 5, 11698. [CrossRef] [PubMed]

38. Kurbatsky, V.I. Opredelitel Vidov Roda Potentilla L. (Lapchatka) Aziatskoi Rossii; Izdatelstvo TGU: Tomsk, Russia, 2016; pp. 6-34.

39. Wen, J.; Zimmer, E. Phylogeny and biogeography of Panax L. (the ginseng genus, Araliaceae): Inferences from ITS sequences of nuclear ribosomal DNA. Mol. Phylogenet. Evol. 1996, 6, 167-177. [CrossRef] [PubMed]

40. Shaw, J.; Lickey, E.B.; Beck, J.T.; Farmer, S.B.; Liu, W.; Miller, J.; Siripun, K.C.; Winder, C.T.; Schilling, E.E.; Small, R.L. The tortoise and the hare II: Relative utility of 21 noncoding chloroplast DNA sequences for phylogenetic analysis. Am. J. Bot. 2005, 92, 142-166. [CrossRef] [PubMed]

41. Shaw, J.; Lickey, E.B.; Schilling, E.E.; Small, R.L. Comparison of whole chloroplast genome sequences to choose noncoding regions for phylogenetic studies in angiosperms: The tortoise and the hare III. Am. J. Bot. 2007, 94, 275-288. [CrossRef]

42. Katoh, K.; Standley, D.M. MAFFT multiple sequence alignment software version 7: Improvements in performance and usability. Mol. Biol. Evol. 2013, 30, 772-780. [CrossRef] 
43. Katoh, K.; Misawa, K.; Kuma, K.; Miyata, T. MAFFT: A novel method for rapid multiple sequence alignment based on fast Fourier transform. Nucleic Acids Res. 2002, 30, 3059-3066. [CrossRef]

44. Hall, T.A. BioEdit: A user-friendly biological sequence alignment editor and analysis program for Windows 95/98/NT. Nucleic Acids Symp. Ser. 1999, 41, 95-98.

45. Stamatakis, A. RAxML version 8: A tool for phylogenetic analysis and post-analysis of large phylogenies. Bioinformatics 2014, 30, 1312-1313. [CrossRef]

46. Kozlov, A.M.; Darriba, D.; Flouri, T.; Morel, B.; Stamatakis, A. RAxML-NG: A fast, scalable and user-friendly tool for maximum likelihood phylogenetic inference. Bioinformatics 2019, 35, 4453-4455. [CrossRef]

47. Edler, D.; Klein, J.; Antonelli, A.; Silvestro, D. raxmlGUI 2.0: A graphical interface and toolkit for phylogenetic analyses using RAxML. Methods Ecol. Evol. 2020. [CrossRef]

48. Darriba, D.; Posada, D.; Kozlov, A.M.; Stamatakis, A.; Morel, B.; Flouri, T. ModelTest-NG: A New and Scalable Tool for the Selection of DNA and Protein Evolutionary Models, Mol. Biol. Evol. 2020, 37, $291-294$. [CrossRef] [PubMed]

49. Clement, M.; Posada, D.; Crandall, K.A. TCS: A computer program to estimate gene genealogies. Mol. Ecol. 2000, 9, 1657-1659. [CrossRef] [PubMed]

50. Rambaut, A. FigTree v.1.4.3. Available online: http://tree.bio.ed.ac.uk/software/figtree/ (accessed on 16 September 2020).

51. Rozas, J.; Ferrer-Mata, A.; Sánchez-DelBarrio, J.C.; Guirao-Rico, S.; Librado, P.; Ramos-Onsins, S.E.; Sánchez-Gracia, A. DnaSP v6: DNA Sequence Polymorphism Analysis of Large Datasets. Mol. Biol. Evol. 2017, 34, 3299-3302. [CrossRef] [PubMed]

52. Excoffier, L.; Laval, G.; Schneider, S. Arlequin ver. 3.0: An integrated software package for population genetics data analysis. Evol. Bioinform. Online 2005, 1, 47-50. [CrossRef]

Publisher's Note: MDPI stays neutral with regard to jurisdictional claims in published maps and institutional affiliations. 